University of Rhode Island

DigitalCommons@URI

Open Access Master's Theses

1991

\title{
Psychological Variables Mediating AIDS Preventive Behavior: A Preliminary Study with College Students
}

Judith A. Goldman

University of Rhode Island

Follow this and additional works at: https://digitalcommons.uri.edu/theses

\section{Recommended Citation}

Goldman, Judith A., "Psychological Variables Mediating AIDS Preventive Behavior: A Preliminary Study with College Students" (1991). Open Access Master's Theses. Paper 1643.

https://digitalcommons.uri.edu/theses/1643

This Thesis is brought to you for free and open access by DigitalCommons@URI. It has been accepted for inclusion in Open Access Master's Theses by an authorized administrator of DigitalCommons@URI. For more information, please contact digitalcommons-group@uri.edu. 
PSYCHOLOGICAL VARIABLES MEDIATING AIDS PREVENTIVE BEHAVIOR:

A PRELIMINARY STUDY WITH COLLEGE STUDENTS

BY

JUDITH A. GOLDMAN

A THESIS SUBMITTED IN PARTIAL FULFILLMENT OF THE REQUIREMENTS FOR THE DEGREE OF

MASTER OF ARTS

IN

PSYCHOLOGY

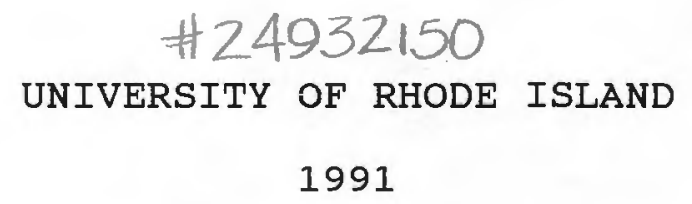




\section{Abstract}

Three psychological variables, subjective control and life meaning, self-efficacy, and perceived risk, were tested in a structural model predicting AIDS preventive behavior. A positive relationship was hypothesized among these variables such that higher measures of subjective control and life meaning, self-efficacy, and perceived risk, would increase the likelihood that a college student would engage in AIDS preventive behavior. In addition, gender differences on the pattern of relationships among the constructs were hypothesized, as well as mean level differences on the measures of these constructs.

The structural model was analyzed with a sample of 633 college students. Subjective control and life meaning constituted the independent variable, the two situationspecific constructs of self-efficacy and perceived risk were mediating variables, and AIDS preventive behavior was the dependent variable. The analyses revealed the model to be a good representation of the data. Overall chi-square statistics and fit indices were adequate, and all individual parameter estimates were significant.

The pathways from subjective control and life meaning to self-efficacy and from self-efficacy to AIDS preventive behavior were positive in direction, indicating that the stronger a person's sense of control over a life which is meaningful, the greater self-efficacy that person feels, and 
the more likely he/she is to engage in AIDS preventive behavior. In contrast, the pathways from subjective control and life meaning to perceived risk, and from these two constructs to AIDS preventive behavior were negative in direction. These results suggest that an individual who feels a sense of competence, control, and purposefulness, is less likely to feel vulnerable to the AIDS virus, and is less likely to take preventive action. Also, in this sample, an individual perceiving vulnerability to HIV infection was less likely to take appropriate precautions.

Finally, the model was analyzed on a sample of 201 men and 401 women, separately. Again, the model performed well on both samples. A multisample model comparing the relationship across constructs for men and women revealed no significant differences in the pattern of these relationships. However, mean differences were revealed on some of the measures of AIDS self-efficacy, AIDS preventive behavior, and AIDS perceived risk, between men and women.

In general, this study indicates that the three psychological constructs of subjective control and life meaning, self-efficacy, and perceived risk, add to our understanding of what may be influencing AIDS preventive behavior in college students. However, further research is needed to identify and test what other psychological, social, and behavioral variables could be relevant in determining why some young adults engage in AIDS preventive behavior and others do not. 


\section{Acknowledgements}

There are numerous people who have made the completion of this project possible, and who deserve special thanks. First and foremost, I would like to thank my major professor, Dr. Lisa Harlow. She has been tremendously supportive, generous with her time and energy, and a true source of inspiration. I would also like to thank Dr. Larry Grebstein and Dr. Leo Carroll, both of whom have offered invaluable insights and knowledge in their specialty areas.

I would like to offer a special thanks to my family. Their constant words of encouragement and support gave me the strength and patience that I needed to complete this project. I feel very blessed to have such support and guidance from those around me. 


\section{Table of contents}

Abstract $\quad$ ii

Acknowledgement iv

Table of contents v

List of Tables vii

List of Figures viii

Introduction 1

Statement of the Research Problem 1

Justification and Significance of the Study 1

AIDS Knowledge 4

Social Norms and Attitudes 5

$\begin{array}{ll}\text { Health Models } & 7\end{array}$

Self-Efficacy 8

Subjective Control and Life Meaning 10

Perceived Risk 13

$\begin{array}{ll}\text { Sex Differences } & 14\end{array}$

$\begin{array}{ll}\text { Research Goals } & 16\end{array}$

$\begin{array}{ll}\text { Method } & 19\end{array}$

$\begin{array}{ll}\text { Participants } & 20\end{array}$

$\begin{array}{ll}\text { Measures } & 20\end{array}$

Data Analysis $\quad 24$

Results $\quad 32$

$\begin{array}{ll}\text { Discussion } & 43\end{array}$

References $\quad 66$ 
Appendix A: Subjective Control \& Life Meaning Scales 80

Powerlessness Scale

Subjective Competence Scale

Life Regard Index

81

Purpose In Life

Appendix B: AIDS Self-Efficacy Scale

Appendix C: AIDS Perceived Risk Scale

86

Appendix D: AIDS Preventive Behavior Scale

Tables

Figures

Bibliography

99 


\section{List of Tables}

Table 1: Descriptive Statistics

Table 2: Descriptive Statistics for Men and Women

Table 3: Correlation Matrix of 7 Variables in Model

90

Table 4: Indices for Overall Fit for AIDS Preventive Behavior Model

Table 5: Standardized Factor Loadings and Error

Variances

Table 6: Standardized Structural Coefficients Among Constructs

Table 7: Indices of Overall Fit for Model Comparisons of Men and women

Table 8: Standardized Factor Loadings and Error Variances for Men and Women 95

Table 9: Standardized Structural coefficients of the Model for Men and Women 


\section{List of Figures}

Figure 1: Hypothesized Model of AIDS Preventive

Behavior

Figure 2: Standardized Solution for Model of AIDS

Preventive Behavior

98

viii 


\section{Statement of the Research Problem}

The AIDS (Acquired Immunodeficiency Syndrome) epidemic is a national health crisis which has recently received substantial attention from behavioral scientists. This attention has focussed on the vital role of behavior change in preventing the spread of the AIDS virus. The purpose of this study is to identify and examine some of the psychological variables that could potentially be associated with AIDS behavioral change. Specifically, three psychological constructs are assessed to determine whether these constructs relate to an individual's commitment to AIDS preventive behavior.

It is hypothesized that the three constructs, subjective control and life meaning, self-efficacy, and perceived risk, will be positively related to AIDS preventive behavior such that people scoring higher on these measures will be more likely to take AIDS preventive action than people scoring lower on these measures. In addition, it is hypothesized that sex differences will be found for these measures, indicating that psychological predictors of AIDS behavioral change are different for men and women.

\section{Justification and Significance of the study}

There is a general agreement among researchers studying the AIDS epidemic, that interventions aimed at changing health behaviors and maintaining these changes are the greatest weapon presently available to combat the AIDS 
crisis (Becker \& Joseph, 1988; Cleary, 1988). As one behavioral scientist commented, "In the absence of effective" vaccines and treatments, prevention of new cases of HIV infections and ultimately, control of the AIDS epidemic, depend upon our success in altering human behavior which results in HIV transmission" (Judson, 1989, p. 879). Although the populations identified as being at greatest risk for contracting the AIDS virus have been homosexuals and intravenous drug users, new studies have documented the spread of the virus among heterosexual women, heterosexual teenagers, and young adults. For example, the proportion of women with AIDS in the heterosexual contact category increased from $12 \%$ in 1982 to $26 \%$ in 1986 (Guinan \& Hardy, 1987). It is estimated that by the end of 1991 at least 18,900 women will be infected with the AIDS virus (Murphy, 1988). As of March 1991 (CDC, 1991), there have been 17,675 reported AIDS cases in women, with the probability that there are many more unreported cases. AIDS has increased so dramatically in New York City that it has become the leading killer of women between the ages of 25 and 34 . Among these women, the majority are minority, low-income women who have limited access to adequate health care (Joseph, 1987). In 1988 HIV infection/AIDS ranked eighth among leading causes of death among women ages 25-44. In 1991, based on current trends, HIV infection/AIDS is likely to rank among the five leading causes of death in this population (MMWR, January, 
1991). New studies indicate that infection rates of younger age groups are now even higher than for older adults in some areas. A study conducted by the Federal Centers for Disease Control found that in areas where AIDS is more prevalent, such as New York and Miami, $1 \%$ of 15 and 16 year olds are already infected and two to three times as many 21 year olds as 15 to 16 year olds are infected. In places in the country where AIDS is less prevalent, 3 in 100015 to 16 year olds are infected, and the rate in 21 year olds is double to triple that of 15 to 16 year olds (Kolata, 1989). Given the levels of sexual activity already documented in this age group, these findings are alarming (McDermott, Hawkins, \& Moore, 1987).

It is clear from the existing data, that efforts to prevent the spread of the AIDS virus must now address the needs of the newest at-risk populations. Unfortunately, research on the effectiveness of preventive measures already established for high-risk populations has been inconclusive. A review of the literature on behavior change among highrisk populations does indicate that the most profound changes in AIDS risking behavior have occurred among some populations of homosexual men. There is also some evidence that intravenous drug users are changing their behaviors (Becker \& Joseph, 1988). Yet, longitudinal studies have shown these changes to be unstable and vulnerable to recidivism (Cleary, 1988). Further, there is still a substantial 
number of individuals in high-risk groups who maintain behaviors which put them at risk for HIV infection. Notably, little modification has been reported in heterosexual young adult populations and urban minority populations (Becker, 1988; Becker \& Joseph, 1988; Strunin \& Hingston, $1987)$.

One major problem in the current research, which has been addressed by a number of researchers, is the general lack of understanding as to why some individuals successfully change their behaviors and others do not (Becker \& Joseph, 1988; Cleary, 1988). Studies have focussed on documenting the magnitude of AIDS-relevant behavioral change but have not attempted to either identify or assess the determinants of this change. In sum, there is a "relative paucity of research on the factors which influence behavioral change" (Becker, 1988, p. 3). One reason cited for this gap in the research is a fundamental difficulty in understanding those behaviors involved in HIV transmission, namely, sexual and drug-using behaviors, which themselves are extremely resistant to change (Judson, 1989). A second reason is that the AIDS prevention strategies already developed have been unable to create consistent and effective changes in behavioral patterns.

\section{AIDS Knowledge}

Prevention strategies aimed at changing AIDS highrisking behaviors have primarily focused on education about 
how AIDS is transmitted and how to protect oneself against infection (Cates \& Bowen, 1989). However, there is strong evidence which shows that risk-reduction efforts based on education alone are, in the long run, unsuccessful (Cates \& Bowen, 1989; Centers for Disease Control, 1989; Gilliam \& Seltzer, 1989; Joseph et al., 1987; Kegeles, 1988; Manning, Barenberg, Gallese, \& Rice, 1989; Rickert, Jay, Gottlieb, \& Bridges, 1989; Valdiserri et al., 1987). Certainly individuals must have knowledge of how to change their behavior in order to do it, but once this knowledge is acquired, there is little empirical evidence currently available to suggest that it is sufficient enough to produce behavior change (Becker, 1988; Becker \& Joseph, 1988). Judson (1989), a physician who has worked nineteen years in the field of preventive medicine, offers two points relevant to these findings. First, he argues that human behavior in general, is weakly driven by knowledge and strongly driven by values, beliefs, and instinct. Second, he believes that the vast majority of new cases of HIV infection in the developed world will occur in individuals who possess all the information they need to prevent infection. Although these ideas are based on experience and not empirical evidence, they are suggestive of the importance of discerning what other factors may be influencing AIDS high-risking behaviors.

\section{Social Norms and Attitudes}

Some researchers have proposed that other conditions 
besides knowledge determine the efficacy of prevention techniques. Fisher (1988), advocated the importance of social norms that networks and reference groups exert on their members, which then influence, either negatively or positively, AIDS preventive behavior. Other researchers have also described the important influences of the individual's context in either promoting or inhibiting AIDS preventive behavior (Amaro, 1988; Cochran \& Mays, 1988; Melton, 1988). In addition, changes in attitudes towards safe-sex practices and towards safe-needle practices have been cited as being important factors in determining preventive action (Becker \& Joseph, 1988; Kegeles, 1988; Rickert, et al., 1989; Strunin \& Hingston, 1987). Some researchers have pointed out that social norms for young heterosexual adults put them at even greater risk for HIV infection (Lawrence, Levy \& Rubinson, 1990; Price, Desmond, Hallinan \& Griffin, 1988; Weisman, Nathanson, Esminger, Teitelbaum, Robinson \& Plitcha, 1989). For example, college students are susceptible to peer pressure regarding sexual activity; they are often willing to experiment with different sexual behaviors, and they tend to have a higher number of sexual partners (Chilman, 1983). In addition, college students are more likely to engage in risk-taking behavior such as heavy drinking, and drug use, both of which have been correlated with unsafe sexual activity (Manning, et. al., 1989; Stall, McKusick, Wiley, Coates \& Ostrow, 1986). It is within this context that the need 
for behavioral research and prevention programs for young adult populations have been emphasized in the literature (Flora \& Thorensen, 1988; Melton, 1988).

\section{Health Models}

However, even when appropriate knowledge and attitudes have been acquired and the culture or subculture is supportive, other barriers to behavioral change exist at the individual level (Becker, 1988; Cleary, 1988). In order to understand the possible factors influencing behavioral change on the individual level, some researchers have begun to apply health models used to study smoking cessation or weight control, to AIDS preventive behavior (Emmons et al., 1986; Manning et al., 1989). The rationale for this research is that successful interventions for other health promoting behaviors may be adapted to promoting safe practices to prevent the spread of AIDS (Flora \& Thorensen, 1988).

The most widely used and studied model of health behavior was proposed by Becker and his associates in 1974, and termed, the Health Belief Model (Janz \& Becker, 1984). The model is a conceptual formulation for understanding why individuals do or do not engage in a wide variety of healthrelated actions (Becker, 1974). Other health models have been proposed called the Health Promotion Model (Pender, 1987), and the Fishbein Model, a theory of reasoned action (Azjen \& Fishbein, 1980). Both of these latter models are 
similar in structure to the Health Belief Model (Cleary, 1988; Weitzel, 1989). There are five major dimensions in the Health Belief Model (HBM): perceived susceptibility, perceived seriousness, perceived benefit, perceived barriers, and perceived likelihood. A review by Janz and Becker (1984) of 46 studies conducted with the Health Belief Model resulted in substantial empirical support for perceived barriers as being the most powerful of the HBM dimensions across various study designs and behaviors. Perceived barriers are defined by Janz and Becker as, "The potential negative aspects of a particular health action which may act as impediments to undertaking the recommended behavior" (p.2). Unfortunately, it is unclear as to what specifically constitutes the perceived barriers to health promoting behaviors in the studies reviewed by Janz and Becker. These researchers, therefore, suggest that further research be conducted to assess the specific factors involved in the perceived barriers dimension.

\section{Self-Efficacy}

Janz and Becker (1984) hypothesize that one variable which may be helpful in breaking through "perceived barriers" is self-efficacy. Self-efficacy as defined by Bandura (1977) is "the conviction that one can successfully execute the behavior required to produce the outcome" (p.193). According to Bandura's theory, the concept of self-efficacy is an important mediating factor between an individual's 
knowledge and the relevant behavior (Bandura, 1982). Evidence, for example, from the smoking cessation literature, shows that the strength of a person's belief in his or her ability to undertake and/or maintain cessation is related to behavior change (Condiotte \& Lichtenstein, 1981). Bandura's concept of self-efficacy has also been found to be relevant in explaining health-promoting behavior using the Health Promotion Model. It has been proposed from this model that believing in one's ability to accomplish a behavior acts as a motivator to perform the behavior (Weitzel, 1989). The concept of self-efficacy has been strongly linked to behavioral performance preventing various health problems (Murdaugh, 1988). For example, those studies which have used self-efficacy as a predictor of health-related behavior have indicated that person's perceptions of their ability to perform a behavior is an important indicator of the likelihood that they perform the behavior (Stretcher, Devellis, Becker \& Rosenstock, 1986). Thus, the construct of selfefficacy is both a useful and important variable to assess when predicting the likelihood that AIDS preventive behavior will be performed (Lawrence, et. al., 1990).

Although it is evident that a lack of self-efficacy. constitutes a perceived barrier in the Health Belief Model, it is still unclear what other psychological factors could be influencing the dimension of perceived barriers. In addition, the Health Belief Model does not claim to account 
for all of the variability involved in an individual's health-related behaviors (Janz \& Becker, 1984). The Health Belief Model, as well as other health models attempts to explain behaviors based on rational, conscious decisions over which individuals have complete control. In this sense, they are inherently limited in the extent to which they can be used to understand more complicated health behaviors influenced by psychological factors (Cleary, 1988). In order to understand the important components of behavioral change on the individual level for AIDS preventive behavior, it is necessary to go beyond established health models and look at more complex psychological variables involved in behavior.

A number of studies in the AIDS literature have alluded to the possibility that AIDS preventive behavior is mediated by complex psychological variables in addition to knowledge, attitudes, and cultural influences (Becker \& Joseph, 1988; Cleary, 1988; Emmons et al., 1986). Although there are some studies which have related psychological variables to AIDS prevention (McCusick, Horstman \& Coates, 1985) there has been little empirical research which attempts to directly identify and test these variables.

\section{Subjective Control and Life Meaning}

one method of identifying psychological variables associated with AIDS preventive behavior is to look at those psychological variables which have been shown to mediate 
other maladaptive, health-risking behaviors. For example, alcohol and drug use, both considered maladaptive healthrisking behaviors, have been shown to be strongly related to non-compliance with safe sex techniques to prevent the spread of AIDS (Stall, et. al., 1986). One psychological factor which has consistently been associated with illicit substance use is a lack of meaning in life (Coleman, Kaplan, \& Downing, 1986; Harlow, Newcomb, \& Bentler, 1986; Newcomb \& Harlow, 1986; Newcomb, Bentler, \& Fahy, 1987; Padelford, 1974; Shean \& Fechtman, 1971). A weak sense of meaning or purpose in life has also been associated with suicide ideation and suicide attempts (Harlow, Newcomb, \& Bentler, 1986; Pilecka, 1985). This concept of the importance in a person's life of a sense of meaning, a sense of purpose derives from Frankl's theory of existential psychology which considers the struggle for an ultimate meaning to existence as being a fundamental, dominant drive of human experience (Frankl, 1963).

Likewise, an individual's perception of feeling in control and competent has been shown to be strongly related to his or her maladaptive behavior (Engel, 1967; Glick, 1983; Harlow \& Newcomb, 1990; Jackson \& Tessler, 1984; Newcomb \& Harlow, 1986). For example, Newcomb and Harlow (1986) found in their study of adolescents, that low personal control, low personal competence, and feelings of powerlessness were related to increased negative behaviors such 
as alcohol and drug use. These researchers also found that perceived lack of control and a lack of meaning in life are strongly related (Harlow \& Newcomb, 1990). In this sense, the belief in one's power and one's sense of control can impact on the feeling that one's life is worthwhile and meaningful. A loss of control tends to lead to psychological distress, and has been implicated in the development of somatic disease (Engel, 1967). Many researchers have maintained that a sense of personal control is integral to one's self-concept and self-esteem (Taylor \& Brown, 1988). "The belief in one's self as a competent, efficacious actor behaving in a world with a generally positive future may be especially helpful in overcoming setbacks, potential blows to self-esteem, and potential erosions of one's view of the future" (p. 201). Perceived lack of control has also been associated with a sense of demoralization which in turn might instigate health-risking behavior (Glick, 1983; Jackson \& Tessler, 1984). It is certainly relevant, therefore, to conclude that person's sense of meaning in life and their feelings of subjective control, including feelings of powerlessness and competence, could influence their commitment to AIDS preventive behavior.

It is important to point out that subjective control and life meaning are differentiated from feelings of selfefficacy in that they constitute a more global, internal construct related to an individual's self-concept. Self- 
efficacy is less global and more situation-specific, as it relates to an individual's perceived capabilities in a given situation.

\section{Perceived Risk}

One factor which has been shown to be particularly relevant as a mediator in the prediction of AIDS preventive behavior is perceived risk or perceived susceptibility (Manning, et. al., 1989; Price, et. al., 1988; Weisman, et. al., 1989). This is especially true for the young adult population who believe they are invulnerable and that AIDS can't happen to them. One group of researchers studying AIDS perceptions among college students described this belief as the egocentrism of the adolescent (Manning, et. al., 1989). The adolescent believes that he or she is magically protected from the things that happen to other people. In addition, the adolescent lives more in the "here and now" and is not generally oriented to a future time perspective. The adolescents' sense of invincibility may inflate their risk of HIV transmission (Lawrence, et. al., 1990). Likewise, the long incubation period for the HIV infection, during which no physical or other manifestations of infection are apparent, complicates the adolescents' ability to realistically perceive their vulnerability. Studies assessing AIDS knowledge, beliefs and perceived risk among college students have emphasized the importance of an individual's perceived susceptibility as a determinant for 
taking AIDS preventive action (Weisman, et. al., 1989). In general, these studies have found that college students rate low on measures of perceived risk. The researchers conclude that college students do not perceive themselves to be susceptible to the AIDS virus because they do not consider themselves to be members of a high-risk group. This is true even when the students score high on measures of AIDS knowledge (Price, et. al., 1988; Simkins \& Kushner, 1986; Sy, Freeze-McElwee, Garrison \& Jackson, 1989). Thus, perceived risk would certainly be a relevant psychological variable in a model that predicts AIDS preventive behavior in a college population.

\section{Sex Differences}

The hypothesis of sex differences for the constructs under study is conceptualized from previous research on women and AIDS and gender differences of perceived efficacy, and other variables. Some researchers studying women and AIDS, for example, have noted the external reality of women's lives that perpetuates a sense of powerlessness and lack of control (Cochran \& Mays, 1988; Murphy;, 1988). Although urban, minority women tend to be most vulnerable to these feelings, the emphasis on cultural forces that "cause women to feel unable or unwilling to assert their right to control their lives," can be said to influence all women who are faced with culturally sanctioned patterns of behavior (Mantell, Schinke, \& Akabas, 1988, p. 31). Researchers 
have, therefore, advocated for prevention programs which not only teach behavioral skills to prevent AIDS, but instill women with a sense of personal control and self-efficacy as well (Harlow \& Grimley, in press; Mantell, et al., 1988). Thus, it could be hypothesized that women may feel less subjective control than men when it comes to behaviors that indicate they have the power and right to control their lives, such as AIDS preventive behavior.

Research conducted on measures of self-efficacy for men and women have consistently shown that gender differences exist, with men typically feeling more efficacious than women. Research in this area portrays the strength of sexrole stereotypes in our cultural which influence perceptions of self-efficacy. For example, research that has measured perceived self-efficacy on performance of gender neutral tasks has shown that females initially judge their selfefficacy to be lower than males', but after skills training, no sex differences on self-efficacy are found (Schunk \& Lilly, 1984). Research on perceived self-efficacy focusing on male-typed tasks, such as mathematics, computer interest, physical ability, and typical male occupations, results in women rating themselves as feeling less efficacious, and/or judging the cause of their success on a particular task as luck rather than skill. (Campbell \& Hackett, 1986; Godin \& Shepard, 1985; Hackett, 1985; Miura, 1987). In this sense, women seem to be more influenced by sex-typed attributions 
rather than their potential skill. Some researchers have proposed that measures of self-efficacy are influenced by gender-related socialization which teaches boys to perceive themselves as having greater ability and more instrumentality than girls (Lee \& Austin, 1986; Vollmer, 1986). Thus, it is possible to expect that men may be more influenced than women by feelings of self-efficacy in their AIDS preventive behavior.

Previous research has already shown gender differences on measures of AIDS knowledge and perceived risk of AIDS (Carroll, 1989; Wilderman Payne \& Akamatsu, 1990). For example, gender differences in the predictors of AIDS knowledge show that men and women seem to acquire knowledge according to their perceived sex role responsibilities. Whereas women learn about AIDS as part of a general learning process of sexuality, fear and intellectual curiosity seem to be the important motivational factors for men. It seems relevant, therefore, to examine the possibility of gender differences in predicting AIDS preventive behavior.

\section{Present Research Goals}

As stated above, the primary purpose of this study is to investigate a number of psychological variables which could be related to AIDS preventive behavior. Given the general lack of research attempting to identify the complex psychological variables underlying AIDS prevention behavior, the variables which have been chosen in this study derive 
from research which has focused on the determinants of either health-risking or health promotion behaviors in the AIDS literature as well as other health-related areas. The hypotheses of this study to be tested using statistical analyses are as follows:

1. Subjective Control and Life Meaning will be positively related to Self-Efficacy for both men and women. 2. Subjective Control and Life Meaning will be positively related to AIDS preventive behavior for both men and women. 3. Perceived Risk will be positively related to AIDS preventive behavior for both men and women.

4. Self-Efficacy will be positively related to AIDS preventive behavior for both men and women.

5. The pattern of relationships across variables in the prediction model will be different for men and women, such that a stronger relationship will exist for men between the constructs of Self-Efficacy and AIDS Preventive Behavior; and a stronger relationship will exist for women between the constructs of Subjective Control and Life Meaning and AIDS Preventive Behavior.

6. The mean level of relationships across variables will vary for men and women such that:

a. Mean differences will be found on the measures of subjective competence and powerlessness, such that women will feel less Subjective Control than men. b. Mean differences will be found on the construct of 
Self-Efficacy such that men will have higher scores than women.

These hypotheses can be summarized into a general prediction that the degree to which one has a sense of selfefficacy, perceived control over one's actions with a sense of meaning in life, and a sense of perceived risk, will influence whether or not one engages in AIDS preventive behavior, and this may differ in degree between men and women. This study does not make the assumption that those variables chosen are the only possible psychological variables affecting AIDS preventive behavior. Rather, this study is exploratory in nature with the understanding that human behavior is influenced by many complex phenomena.

The importance of a study focusing on the determinants of behavioral change in AIDS high-risking behavior cannot be overemphasized. If behavioral change is our greatest weapon against the spread of the AIDS virus, it is imperative that we try to understand as much as we can about what factors both motivate and maintain prevention behaviors. A study which adds to our understanding of why an individual does or does not exhibit AIDS preventive behavior could provide a valuable resource for intervention programs, as well. For example; public health programs could use this information to design interventions which provide individuals with the technical, interpersonal and internal skills necessary to undertake and maintain behavioral changes to reduce the risk 
of AIDS (Becker, 1988; Harlow \& Grimley, in press). Cleary (1988) emphasizes this idea by stating that in order for public health programs to be effective, they "should incorporate basic principles of health education and be sensitive to the complex psychological factors motivating and sustaining behavior, as well as the social and cultural determinants of individual behavior" (p. 267).

Finally, it is important to investigate these hypotheses because high risk populations and those populations of increasing risk for contracting the AIDS virus, namely heterosexual minority women and heterosexual young adults, might already be vulnerable to feelings of powerlessness, lack of control, lack of self-efficacy, and lack of meaning in life. Hopefully, this study will be able to add a piece to the AIDS prevention literature, and in doing so, will stimulate further investigation of the psychological determinants of AIDS behavioral change.

\section{Method}

This study is a secondary analysis on a data base of college students at the University of Rhode Island, collected by Dr. Lisa Harlow, in March 1989. Students were asked to volunteer for $\mathrm{Dr}$. Harlow's research, and approximately half of those students received course credit for participation. Students were recruited from undergraduate psychology courses. Participants signed an informed consent form, 
entitled, "Young Adults Life Experiences Questionnaire." They were told that the questionnaire would ask them about their feelings about themselves, their experiences, and their attitudes, knowledge, and behavior regarding AIDS and other behaviors. All information was held strictly confidential by assigning each subject a number that was not associated with the subject's name. The students were given a packet to complete and return to $\mathrm{Dr}$. Harlow. The paper and pencil questionnaire took approximately one hour to complete.

\section{participants}

Participants who completed the questionnaire included 201 males, 401 females, and 31 students who did not indicate their sex $(\mathrm{N}=633)$. Their mean age was 20 years old, ranging from 19 to 45 years of age. The ethnicity breakdown was $88 \%$ Caucasian, 3\% Hispanic, 3\% Black, 3\% Asian, and 3\% other. The majority were Catholic and middle-class.

\section{Measures}

Seven measures are examined in this study to operationally define the four constructs of subjective control and life meaning, self-efficacy, perceived risk, and AIDS preventive behavior.

Self-Efficacy is measured from an average composite score on an AIDS efficacy scale of four questions developed by Harlow (1989). A list of the four items is presented in Appendix B. The variables which are used to measure this 
construct are elaborating on Bandura's (1977) theory and definition of self-efficacy which propose that the extent to which an individual believes that he/she has the capability to achieve a successful outcome, will influence the likelihood of that individual's performing any given behavior. The AIDS efficacy scale, therefore, gives an indication of a subject's perceived ability to behave in ways which would successfully prevent AIDS infection. An estimate of internal consistency for this scale, calculated on the data, yielded an alpha coefficient of $\alpha=.72$.

Subjective Control and Life Meaning incorporates two factors that are highly correlated into one global construct. One factor is subjective control which is operationally defined as an individual's perception that he/she has the capacity to control and effect change in his/her life. The variables measuring this aspect of the overall construct reflect the belief that one has the power and inner resources to act upon the world, rather than accept whatever the world has to offer. There are two measures as indicators of subjective control. The first is the average score of a 5-item scale measuring powerlessness (see Newcomb \& Harlow, 1986), which serves as a negative indicator. This scale has been used in previous research (e.g. Harlow \& Newcomb, 1990; Newcomb \& Harlow, 1986) and has been shown to measure an individual's sense of powerlessness and lack of control over his/her 1ife. A measure of internal consisten- 
cy calculated for this study yielded an alpha coefficient of $\alpha=.82$. The second measure is the average of a 12-item scale assessing subjective competence (Harlow, 1989), which serves as a positive indicator. The subjective competence scale derives from Jerome Frank's (1974) theory of demoralization which proposes that there are two measurable components of demoralization; distress and subjective competence. The subjective competence scale measures a person's perceived capacity to perform tasks and/or express feelings which he/she considers appropriate in a given situation (DeFigueiredo \& Frank, 1982). An estimate of internal consistency for the data in this study yielded an alpha coefficient of $\alpha=.88$.

The second factor in this global construct, life meaning, is based on Frankl's (1963) theory of existential psychology, which emphasizes the importance in the human experience, of finding an ultimate meaning to existence. Life meaning is operationally defined as an individual's belief in a positive framework, within which life is seen as fulfilling and significant. This aspect of the construct consists of two measures. The first measure is the average of the 20-item Purpose in Life scale developed by Crumbaugh \& Maholick (1964), and revised by Harlow, Newcomb, and Bentler (1987). The second measure is the average of the 28-item Life Regard scale developed by Battista and Almond (1973). Both scales have been shown to be reliable and valid 
measures of Frankl's theory of meaning in life, although the Purpose in Life scale has received wider attention and use than the Life Regard scale (Battista \& Almond, 1973; Chamberlain \& Zika, 1988; Crumbaugh, 1968; Crumbaugh \& Maholick, 1964). Measures of test-retest reliability for the Life Regard scale have been reported at .94 (Battista and Almond, 1973), and for the Purpose in Life scale at .79 over a 6week interval (Reker \& Cousins, 1979). Split-half correlation tests for reliability of the Purpose in Life scale have yielded coefficients of .85 , corrected by the Spearman-Brown formula to .92 (Crumbaugh, 1968) and .77, corrected to .87 (Reker \& Cousins, 1979). The Life Regard scale has been demonstrated to have construct validity by successfully differentiating $(p<.05)$ medical students with high and low meaning in life (Battista \& Almond, 1973). The Purpose in Life scale has been shown to have construct validity by significantly $(p<.01)$ discriminating between "normals" and psychiatric patient samples (Crumbaugh, 1968; Crumbaugh \& Maholick, 1964). In this study, measures of internal consistency calculated for each scale resulted in alpha coefficients of $\alpha=.83$ for the Purpose in Life scale and $\alpha=.94$ for the Life Regard Index. A list of the items constituting each scale is presented in Appendix $A$.

The construct of Perceived Risk is operationally defined as an individual's perception that he or she could be at risk for contracting the AIDS virus. This construct is 
measured by the average composite score of four questions on an AIDS perceived risk scale (Harlow, 1989). These questions assess how vulnerable the individual feels in regards to his/her past behavior and/or current situation. For example, one question asks the individuals to rate whether they suspect they may have been exposed to the AIDS virus. Another, asks individuals to rate whether they feel they are currently at risk of getting AIDS. All four items are presented in Appendix C. An estimate of internal consistency calculated for the data in this study yielded an alpha coefficient of $\alpha=.78$.

Finally, AIDS Preventive Behavior is measured by an average composite score of four questions developed by Harlow (1989). This scale measures whether or not an individual engages in certain "safer sex" behaviors which have been recommended as guidelines to avoid HIV infection (Koop, 1987). For example, the scale examines condom use, as well as degree of sexual activity, two behaviors which have been identified as modifiable AIDS-preventive behaviors (Centers for Disease Control, 1986; Koop, 1987). A list of the four items is presented in Appendix D. A measure of internal consistency calculated for this study resulted in an alpha coefficient of $\alpha=.70$.

Data Analysis

The data were analyzed using structural equation modeling techniques to examine the relationships between the 
independent variable of subjective control and life meaning; the mediating variables of self-efficacy and perceived risk; and the dependent variable, AIDS preventive behavior. In the model, the independent construct conceptualized as subjective control and life meaning, is viewed as a global, subjective concept which is not directly measured by specific situational factors. The construct describes persons' perceptions of themselves as competent agents in a world in which they experience a sense of control and meaning. In comparison, the mediating constructs of self-efficacy and perceived risk, defined as AIDS efficacy and AIDS perceived risk, are viewed as more behavioral, situationally-related measures which mediate between a subjective measure and the measurable outcome of AIDS preventive behavior. A comparison of males and females on these measures was also conducted to test for sex differences. A diagram of the design paradigm is presented in Figure 1.

\section{Insert Figure 1 about here}

The technique of structural modeling was chosen for these analyses because it has several advantages over other statistical techniques (e.g. Harlow, et al., 1986). As a multivariate statistical technique, structural modeling combines the best of the procedures of multiple regression, factor analysis, and path analysis into one methodology. Linear combinations of observed variables representing 
underlying, latent variables are created and regressions are hypothesized among the latent constructs. These regressions can then be evaluated in a path analytic framework in which the relationships among the observed and latent variables are considered simultaneously. Thus, one is able to assess the degree of relationship among multiple independent and dependent variables, assess potential causal influences and their directions between variables, and finally, reveal relationships between observed (measured) variables and latent variables (constructs).

Based on these statistical advantages, structural modeling was chosen to test the hypothesized model, over other multivariate statistical techniques such as multiple regression. One reason, specific to this study, is that multiple regression only allows for multiple independent variables which predict one dependent variable. With structural modeling, mediating variables can be included and the relationships among these variables can be assessed simultaneously. This capability is important for the hypothesized model because it is then possible to assess the relevance of self-efficacy and perceived risk as potential mediators between the existential construct of subjective control and life meaning and AIDS preventive behavior. Secondly, multiple regression assesses the significance of variables as they account for the variation in the dependent variable. If the independent variables are highly correlated, it can 
cause collinearity, and the regression equation becomes unreliable. In the hypothesized model, the only construct which is measured with multiple observed variables is subjective control and life meaning. The four variables which together form this construct are highly correlated, and therefore, could not be assessed adequately in a multiple regression equation. Likewise, because subjective control and life meaning is the only independent construct in the model, and because it is a latent construct of four measured variables, the relationships among this construct and the other constructs is unbiased.

Structural modeling techniques were chosen for this study for some other important reasons, as well. For one, it has been proposed that complex health-related behaviors such as those being assessed in this study, are best measured and their relationships best understood with structural modeling equations (Chen \& Land, 1986; Kennedy, Starrfield \& Baffi, 1983). The reasons for this choice among methodologists involve the statistical procedure. Structural modeling allows for constructs to be measured with more than one factor and, therefore, the constructs are seen as more robust and comprehensive. In addition, measurement error is recognized and accounted for in the measurement model so that the constructs and the relationships among them are unbiased; that is, not confounded with error when each construct has two or more measures. With both measurement 
error and prediction error systematically taken into account, one is able to be more confident in the reliability of the results of the analyses (Bentler, 1980).

A number of researchers have used structural modeling to test health-related models including adherence to medical regimens (Stanton, 1987), preventive dental behavior (Chen \& Land, 1986), predicting health practices (Yarcheski \& Mahon, 1989), and adaptive/maladaptive coping with a health threat (Ripptoe \& Rogers, 1987). Although structural modeling has not yet been widely used to specifically test models of predicting AIDS preventive behavior, it is supported in the literature as being a highly useful and meaningful statistical technique (Bollen, 1989; Carmines, 1986).

Two of the most widely used computer programs for analyzing structural models are LISREL (Joreskog \& Sorbom, 1986) and EQS (Bentler, 1985). LISREL is appropriate to use when the variables in the model are normally distributed. In this case, maximum likelihood estimation (ML) is conducted to evaluate whether or not the model is plausible in explaining the data. When the variables in the model are not normally distributed, it is more appropriate to utilize the nonnormal methods of estimation available in EQS. For this study, the distribution of the variables did not meet the assumptions of normality; therefore, EQS was the program of choice for these analyses.

It is fairly typical to attain a data set which is 
nonnormal when studying phenomena such as risk-taking behaviors and issues relevant to AIDS. When faced with analyzing nonnormal data, there are a number of methods one can use. First, the nonnormality of the data can be acknowledged and then corrected for by a transformation of the original data. For example, descriptive statistics should be calculated and presented; then transformations can be conducted on the data, such as square root and logarithmic transformations. A second method of working with nonnormal data is to use estimators which are developed with less restrictive distributional assumptions. In the EQS program, the estimators of ML (maximum likelihood) with ROBUST statistics, ERLS (elliptical reweighted least squares), and ADF (arbitrary distribution free) are procedures of estimation which allow for nonnormality. The method of ML by itself assumes that the data is normally distributed. If these assumptions are not met, the statistics derived from ML, particularly the chisquare and standard errors, are less reliable. However, with the ROBUST statistics which have recently become available in EQS, distributional misspecifications can be corrected by using the Satorra-Bentler $(1988 \mathrm{a}, \mathrm{b})$ scaled chisquare and robust standard errors. Preliminary evidence has shown these statistics to be more trustworthy than ordinary statistics when the normal distribution assumption is violated (Chou, Bentler, \& Satorra, 1989). ERLS is an estimation procedure which is more relaxed about distribution 
assumptions than ML because it allows for equal, nonzero kurtoses in the data. However, ERLS is more restricted than ADF because it does not allow for nonnormal skewness, while ADF allows for both nonnormal skewness and kurtosis. Both ERLS and ADF have disadvantages as estimation procedures. ERLS has been found to overcorrect for kurtosis causing the chi-square measure of overall fit for the model to be slightly smaller than the expected value (Harlow, 1985), although other researchers have found ERLS to be less biased than ML (Sharma, Durvasula, \& Dillon, 1989). ADF is a procedure which requires a very large sample size in order to correctly estimate a measure of overall fit for the model, and when the sample size is not large enough, the solution may not converge (Tanaka, 1984). Taking the various advantages and disadvantages of the available estimation procedures into account, those chosen for this study are ML (ROBUST) and ERLS, and both will be reported and compared in the results.

The plausibility of an hypothesized structural model. is evaluated in terms of overall fit of the model to the data, and the significance of the individual parameter estimates in the model. Overall model fit is assessed by the chisquare statistic, which should be nonsignificant if the model and data are close in fit.

The chi-square statistic is mathematically sensitive to sample size such that the larger the sample, the larger the 
chi-square (Bentler \& Bonett, 1980). Thus, other indices of model appropriateness will also be examined that are not as sensitive to sample size. Overall fit is also assessed by the root mean residual index (RMSR) which indicates the amount of variance and covariance in the data for which the model is not accounting.

Various incremental fit indices are also calculated to evaluate overall fit. There is no general consensus as to which fit index is most appropriate to use and therefore, a number of indices are often reported (Marsh, Balla, \& McDonald, 1988. The fit indices which are calculated in EQS are the Normed Fit Index (NFI) (Bentler \& Bonett, 1980), the non-normed fit index (NNFI) (see Tucker \& Lewis, 1973), and the Comparative Fit Index (CFI) (Bentler, 1990). Another fit index has been proposed by James, Mulaik, \& Brett $(1982,1987)$ which involves taking a calculated parsimonious ratio and multiplying it by the other fit indices, to get a Parsimonious Fit Index. This adjusted fit index takes into account the degrees of freedom of the model, indicating the effectiveness of the structural coefficients, given the number of parameter estimates used to explain the data. These latter indices may be preferable to chi-square since they are less dependent on sample size, and so were selected for use in this study.

A structural model is considered to be a good fit of the data when the chi-square statistic is close to the 
degrees of freedom in value, the root mean square residual is close to zero, the fit indices which range from $0-1$, are close to 1 , and the hypothesized parameter estimates are statistically significant according to their individual zscores.

The plausibility of a model can also be evaluated using methods of repetition and replication. One such method involves comparisons of the same model with different samples. For example, if the data set is large enough, comparisons can be conducted by randomly splitting the data set and analyzing the model on both halves (Cudeck \& Browne, 1983). Or the model can be analyzed using a multisample model, which compares two different samples on the same model, by constraining various pathways to determine whether or not significant differences exist between the samples. Nested model comparisons can also be conducted to assess the usefulness of mediating variables and to ascertain whether certain pathways are necessary for a good model fit. Each of these methods of repetition and replication are utilized in the present study.

\section{Results}

Descriptive statistics for the data are shown in Table 1. Relative to the total range for each variable, this sample appears to show high levels of control, competence, meaning in life, purpose in life, life regard, and AIDS 
self-efficacy. AIDS prevention behavior scores are in the moderate range and AIDS perceived risk scores are reportedly fairly low. The means, standard deviations, skewnesses and kurtoses are reported for all variables of interest from the entire sample in Table 1, and then for men and women separately in Table 2 .

\section{Insert Tables 1 and 2 about here}

Logarithmic transformations were conducted on the data for AIDS perceived risk, AIDS self-efficacy and AIDS preventive behavior, due to the nonnormal distribution of these variables. The use of log transformations is supported by Tabatchnick and Fidell (1989) who emphasize the appropriateness of using transformations with data that is highly skewed or kurtotic. However, a comparison of these variables with and without the log transformations revealed that for all three variables, the transformations did not adequately change the skewness and kurtosis; and for the variable of AIDS self-efficacy, the log transformation actually made the distribution more nonnormal (see Table 1). Therefore, the preliminary analyses were conducted without the use of transformations on any of the AIDS variables.

A Correlation matrix of all seven variables is presented in Table 3 . 
The correlation matrix shows strong relationships among the four variables measuring subjective control and life meaning. These variables, individually, appear to have a weak relationship to AIDS preventive behavior. Self-efficacy appears to be positively correlated with AIDS preventive behavior, whereas perceived risk shows a negative relationship to AIDS preventive behavior.

Bentler's (1985) EQS program was used to analyze the proposed model. All analyses were conducted twice, using the estimation procedures of Maximum Likelihood with Robust Statistics (ML,ROBUST) and Elliptical Estimation (ERLS). Results from both procedures are reported. A comparison of the results of the analyses using both estimation procedures, reveal almost identical parameter estimates. Given this expected finding, a discussion of the results could emphasize either estimation procedure. For this study, the results from ERLS estimation will be the focus of the discussion. This choice is based not only on the similarity of the findings with the two procedures, but also on findings of other researchers who propose that Elliptical Estimation may be the better procedure to use with nonnormal data (Sharma, Durvasula, \& Dillon, 1989).

The results of the analyses conducted for the hypothesized model reveal a plausible fit of the model to the data 
(see Table 4).

\section{Insert Table 4 about here}

The chi-square statistic was $X^{2}=50.18$, with $\mathrm{df}=12$. The Root Mean Square Residual (RMSR) was $=.03$, indicating that the model is accounting for a good portion of the variation and covariation in the data. Fit indices were NFI $=.97$, NNFI $=.96$, CFI $=.98$, PNFI $=.55$, PNNFI $=.55$, PCFI $=.56$, which indicate good model fit.

All individual parameter estimates were significant at $\mathrm{p}<.001$ or better. Figure 2 displays the model with its standardized parameter estimates.

\section{Insert Figure 2 about here}

Factor loadings for all four indicators of subjective control and life meaning were significant at $p<.001$ (powerlessness $=-.80$, subjective competence $=.74$, purpose in life $=.90$, life regard index $=.75$ ) (see Table 5). Regression pathways were all significant but the direction of the relationships between the constructs were, in some cases, opposite to the hypothesized direction (see Table 6).

\section{Insert Tables 5 and 6 about here}

The construct of subjective control and life meaning was positively related to the construct of self-efficacy 
(.38) suggesting that the more an individual has a sense of being in control of his/her life, and feels positive about the future, the more the individual is likely to feel that he/she can successfully prevent contraction of the AIDS virus. Self-efficacy was positively related to AIDS preventive behavior $(.32)$ indicating that the individual who feels he/she can successfully prevent HIV infection is more likely to take AIDS preventive action. These results support the original hypotheses proposed for the direction of the relationships among these constructs.

The construct of subjective control and life meaning was found to be negatively related to both perceived risk $(-.22)$ and AIDS preventive behavior (-.24). These results suggest that the greater one's sense of control and purpose in life, the less one feels vulnerable to a fatal disease such as AIDS and, therefore the less likely one is to take appropriate precautions against contracting the virus. In addition, the construct of perceived risk was negatively related to AIDS preventive behavior (-.33) which seems to suggest that an individual who feels vulnerable to contracting AIDS is less likely to engage in AIDS preventive behaviors. Although all the relationships were statistically significant, the direction of these relationships did not support the hypothesized directions.

In order to assess how well the model accounted for the variance of the individual constructs, calculations of 
squared multiple correlations were conducted (i.e. $R^{2}=1-$ prediction error variance). The construct of subjective control and life meaning was found to account for $5 \%$ of the variance of AIDS perceived risk $\left(R^{2}=.05\right)$, and $15 \%$ of the variance of AIDS self-efficacy $\left(R^{2}=.15\right)$. The three constructs taken together, accounted for $19 \%$ of the variance of AIDS preventive behavior $\left(R^{2}=.19\right)$.

Further Examination of the Model

To further test the fit of the model, a number of comparisons of the model were performed. First, a multisample model was conducted on a split half of the original data set. All four factor loadings and five regression paths were constrained to be equal. If any of the resulting chisquare statistics for the path constraints are significant, it indicates that the constrained parameter in the model is not the same across data sets and needs to be estimated separately in order to more adequately describe the data. Results from the overall fit of the multisample model revealed a chi-square of $\mathrm{X}^{2}=80.707$, with df $=33$. Fit indices were NFI $=.96, \mathrm{NNFI}=.97, \mathrm{CFI}=.98, \mathrm{PNFI}=.75$. PPNFI $=.76$, PCFI $=.76$, indicating a plausible fit of the model with the data. All but one of the constraints were found to be nonsignificant using $\mathrm{p}<.01$ which suggests that the model is largely an acceptable representation of the data across samples. The path that was significant at $p<.01$ was the factor loading of the life regard index on the 
construct subjective control and life meaning. This finding indicates that this path is not consistent across samples. An explanation of this finding is discussed by Bentler (1985), who states that constraining all parameters in a model to be equal is highly restrictive, because it assumes that all the derived covariance matrices are identical across populations. Since this is unlikely to be true, some "nuisance" parameters may tend to differ across samples.

Next, a nested model comparison was performed to ascertain the relevance of the mediating variables AIDS selfefficacy and AIDS perceived risk. First, the model was analyzed with the four structural paths connected to AIDS self-efficacy and AIDS perceived risk fixed at zero (df $=$ 16). The resulting chi-square statistic and degrees of freedom were then compared to the chi-square statistic for the original structural model $(d f=12)$. Results revealed a significant chi-square of $\mathrm{X}^{2}=239.099$, df $=4$, indicating that the model fit was significantly worse when the mediating paths were removed. Thus, the mediating variables of AIDS self-efficacy and AIDS perceived risk are necessary for the model to fit the data well.

Finally, a comparison of the model was conducted for men and women to assess the pattern of relationships across the constructs for each gender. The model was first analyzed with a sample of 201 men only $(\mathrm{N}=201)$ (see Table 7). 
The chi-square was $\mathrm{X}^{2}=21.600$, with df $=12$. The RMSR was .03. Fit indices were $\mathrm{NFI}=.96, \mathrm{NNFI}=.97, \mathrm{CFI}=.98$, PNFI $=.55$, PNNFI $=.56$, PCFI $=.56$, indicating a relatively good fit of the model to the data. Parameter estimates were all significant at $p<.01$ or better (see Tables 8 \& 9).

\section{Insert Tables 8 and 9 about here}

Squared multiple correlations were performed revealing that subjective control and life meaning accounted for $10 \%$ of the variance of AIDS perceived risk $\left(R^{2}=.10\right), 17 \%$ of the variance of AIDS self-efficacy $\left(R^{2}=.17\right)$, and all three constructs accounted for $20 \%$ of the variance in AIDS preventive behavior $\left(\mathrm{R}^{2}=.20\right)$.

The model analyzed with 401 women $(\mathrm{N}=401)$ resulted in a chi-square of $\mathrm{X}^{2}=47.310$, with df $=12$. The RMSR was .03. Fit indices were NFI $=.96, \mathrm{NNFI}=.95, \mathrm{CFI}=.97$, $\mathrm{PNFI}=.55, \mathrm{PNNFI}=.54$, and $\mathrm{PCFI}=.56$. All parameter estimates were significant at $p<.01$ or better. Calculated square multiple correlations showed that subjective control and life meaning accounted for $3 \%$ of the variance of AIDS perceived risk $\left(R^{2}=.03\right), 13 \%$ of the variance in AIDS selfefficacy $\left(R^{2}=.13\right)$, and the three constructs accounted for $17 \%$ of the variance in AIDS preventive behavior $\left(R^{2}=.17\right)$. 
Overall, these indices indicated a reasonable fit of the model to the data for women, though the overall fit indices and explained variance were slightly better for the data with the men.

Although the model was shown to be a plausible fit of the data for both men and women, these results did not indicate whether the pattern of relationships for the constructs hypothesized in the study, was different for each sex. Therefore, to test whether or not the individual relationships among the constructs would be different for men and women, a multisample model was performed. The parameters constrained to be equal included the factor loadings of subjective competence and powerlessness on subjective control and life meaning, and the regression coefficients for the paths from self-efficacy and subjective control and life meaning, to AIDS preventive behavior. The multisample model was analyzed using logarithmic transformations of the AIDS variables because the statistical variability of the parameter estimates could not be accurately computed for the sample of men with ERLS or Robust procedures. When the untransformed AIDS variables were used, the diagonal element of the covariance matrix of estimates was negative, causing the computation of parameter estimates to be indeterminate. Thus, results of the model were shown to be more reliable when the model was analyzed using the logarithmic transformations with ML and ERLS estimation 
procedures. Results from the multisample model revealed the overall fit chi-square to be $x^{2}=58.47$, with df $=28$. The RMSR was .03 . Fit indices were NFI $=.96$, NNFI $=.97$, CFI $=.98, \mathrm{PNFI}=.64, \mathrm{PNNFI}=.65, \mathrm{PCFI}=.65$, indicating an acceptable model fit. All parameter estimates were significant at $\mathrm{p}<.01$ or better. The chi-squares for all four parameter constraints were nonsignificant at $p<.01$, indicating that there is no evidence that the paths from powerlessness and subjective competence to subjective control and life meaning, and from self-efficacy and subjective control and life meaning to AIDS preventive behavior vary across the data samples for men and women. Accordingly, the relationships among the constructs of self-efficacy, subjective control and life meaning and AIDS preventive behavior are similar for men and women. Therefore, the hypothesis that gender differences exist in the pattern of the relationships among these variables was not supported.

To test the hypothesis of gender differences on the mean levels of the variables in the study, a MANOVA was performed with sex as the independent variable, and all twelve AIDS items, as well as subjective control, and life meaning as the separate dependent variables. Results revealed significant gender differences overall, with $T^{2}$ $(14,587)=146.96$, at $p<.001$. Individual ANOVAS were then conducted to examine on which items these gender differences occurred. To correct for inflation of Type I error rate, 
follow-up tests were required to reach at least the .01 level of significance. It was hypothesized that gender differences would be revealed on the mean level of the variables, subjective control and self-efficacy, with women scoring significantly lower on these measures than men. Results showed no significant differences on the mean level of subjective control for men and women. Significant differences were found on all four items of the AIDS selfefficacy scale, with women scoring significantly higher on these items than men $(\mathrm{p}<.01)$ (see Table 2). In addition, gender differences were revealed on three of the items of AIDS perceived risk, and three of the items of AIDS preventive behavior. Significant gender differences were not shown on measures of life meaning, condom use, and fears of being exposed to the AIDS virus (see Table 2 ). Post Hoc Analyses

Post hoc analyses were conducted to see if the construct of perceived risk could be measured more effectively in the model as an outcome variable. These analyses were also conducted to specifically assess the relationship between perceived risk and AIDS preventive behavior. The results indicated that this model fit was slightly less plausible than the original hypothesized model. The chisquare was $\mathrm{X}^{2}=82.91$, with $\mathrm{df}=12$; the Satorra-Bentler chi-square was $X^{2}=81.49$. Fit indices were NFI $=.95$, NNFI $=.92, \mathrm{CFI}=.96, \mathrm{PNFI}=.54, \mathrm{PNNFI}=.52, \mathrm{PCFI}=.55$. 
Regression pathways were all significant at $p<.01$ except for the pathway between subjective control and life meaning and AIDS preventive behavior, which was non-significant. All three constructs, subjective control and life meaning (-.17), self-efficacy (-.14), and AIDS preventive behavior (-.33) were negatively related to perceived risk. Finally, the model with perceived risk as the outcome variable, was shown to account for $18 \%$ of the variance of perceived risk $\left(R^{2}=.18\right), 14 \%$ of the variance of self-efficacy $\left(R^{2}=.14\right)$, and less than $1 \%$ of the variance of AIDS preventive behavior $\left(R^{2}=.002\right)$.

\section{Discussion}

The results of this study suggest that psychological variables do play a role in predicting whether or not a college student engages in AIDS preventive behavior. All three constructs, subjective control and life meaning, selfefficacy, and perceived risk significantly related to AIDS preventive behavior. The original model was shown to be a plausible fit of the data which underscores the need for including psychological variables in an understanding of why some people perform AIDS preventive behaviors and others do not. A post hoc model with perceived risk as an outcome did not appear to represent the data as well as the original model of AIDS preventive behavior.

In order to fully evaluate the structural model proposed in this study, and make some interpretations about the 
data based on the results, both overall fit and individual parameter estimates need to be examined. Overall fit is best established by the fit indices because the chi-square statistic that is calculated is somewhat biased by the size of the sample. Nevertheless, the chi-square statistic should be low, reaching non-significance for a model to be judged as a plausible fit. In this study, the chi-square statistic for the hypothesized model was low, yet significant. Notably, the Satorra-Bentler Scaled chi-square statistic that is designed to have a distribution that is more closely approximated by chi-square than the usual test statistic (Satorra \& Bentler, 1988a,b) performed better than the test statistic of ML by itself or ERLS estimation, thus supporting the use of ROBUST statistics in the handling of nonnormal data.

Fit indices have been developed for structural modeling techniques to ascertain the fit of the proposed model relative to the null hypothesis which assumes no relationship between the constructs. Fit indices greater than .90 are considered to be an indication of good model fit, with values closer to 1 , indicating better overall fit. The fit indices for all analyses performed with this model using both Maximum Likelihood (ML, Robust) and Elliptical Distribution (ERLS) estimators, ranged from .93 to .98, which show very good overall fit. The parsimonious fit indices calculated for ML (Robust) and ERLS estimation procedures, using 
the parsimonious ratio ranged from .53 to .77 in this study. Although the values for parsimonious fit indices should ideally be close to 1.0 , they are usually much lower and the values derived for the current model are reasonable. Thus, the overall fit for the structural model proposed in this study is acceptable and the model can be judged to be a plausible representation of the data.

Another assessment of overall model fit is the Root Mean Square Residual (RMSR) which explains that amount of variance and covariance of the constructs which is not taken into account by the model. These indicators should be close to zero, and are judged to be acceptable when values are less than .06 (Hayduk, 1987). Both the ML (Robust) and ERLS estimators derived similar values ranging from .03 to .05 . These results offer further support for the plausibility of the model, suggesting that the model is explaining a reasonable amount of the variation and covariation in the data.

A further means of looking at the relative fit of the model to the data is through an examination of the individual parameter estimates. Significance of the individual parameter estimates is established through individual zscore ratios of parameter estimate over standard error. Zscore ratios greater than 1.96 indicate significance at $\mathrm{p}<.05$. However, the standard error in $z$-scores tends to be vulnerable to violation of distribution assumptions. In this study, the ML, ROBUST statistic was used to insure 
against inflated standard errors due to nonnormality of the data. A comparison of standard errors with and without the ML, ROBUST correction showed the standard errors to be stable across estimation procedures, which emphasizes the dependability of the $\mathrm{z}$-scores for the individual parameter estimates.

The factor loadings for the four indicators of the latent construct, subjective control and life meaning, were all significant at the probability level of .001 or better. This held true for both ML (Robust) and ERLS estimation procedures. These results are evidence that this portion of the measurement model is well-defined. When the measured variables are shown to be accurate indicators of the constructs, this contributes to the strength of the structural model. All three AIDS constructs were utilized in the model as single indicators so that factor loadings on these measures were fixed at 1.0 and not estimated. In structural modeling it is not ideal to only have one indicator, or scale, as a measure of a given construct. In fact, it is usually recommended that constructs be measured with two or more indicators to insure a purer measure of the construct and unbiased relationships among the constructs. Unfortunately, research on AIDS issues is relatively new and numerous standardized scales have not been developed to measure the constructs. Given these constraints, it is still justifiable and useful to utilize structural modeling techniques 
with these single indicators of the mediating and outcome variables.

The regression coefficients of the prediction model indicate how well the mediating or dependent constructs are being predicted through pathways heading from the other latent constructs. These structural coefficients were all found to be significant, across the various samples testing the model, at the probability level of .01 or better. These findings were consistent for both the ML (Robust) and ERLS estimation procedures. Thus, given the significant results of these analyses, it becomes possible to explore the meaning of the findings and make some inferences about the relationships among the constructs and their relation to AIDS preventive behavior.

It is clear, from the overall fit of the model to the data, that the three psychological variables chosen for this study are relevant to an overall understanding of AIDS prevention behavior in young adults. In particular, the overall fit suggests that the hypothesized arrangement of the constructs in the structural model was appropriate. This finding is also supported by the results from the analysis with nested models, which suggests that the mediating constructs of self-efficacy and perceived risk are necessary in establishing a good fit of the model with the data. Thus, a more global, existential construct such as subjective control and life meaning does significantly 
relate to the two psychological variables of self-efficacy and perceived risk, which are more situation-specific to AIDS prevention. Further, all three of these constructs are related to a young adult's AIDS preventive behavior, with the two specific mediating constructs, self-efficacy and perceived risk, showing a slightly stronger relationship to AIDS preventive behavior than the broader construct of subjective control and life meaning.

The pathway between subjective control and life meaning and self-efficacy was positive (.38), as was the pathway from self-efficacy to AIDS preventive behavior (.32). These results suggest that positive feelings of competence, control and meaningfulness in one's life relate to one's sense of capability that in a situation like the AIDS epidemic, one will take appropriate precautions and successfully prevent HIV infection. The direction of the pathway from self-efficacy to AIDS preventive behavior supports the findings in other studies which have shown self-efficacy to be significantly related to health-related prevention behaviors (Lawrence, et.al., 1990; Stretcher, et. al., 1986).

The pathway from subjective control and life meaning directly to AIDS prevention behavior was significant (-.24), but in the opposite direction than the hypothesized relationship. This finding suggests that the greater an individual's sense of competence, control, and sense of meaning in life, the less likely that individual is to 
engage in AIDS preventive behavior. Initially, these unhypothesized results seem untenable because one would assume that a positive self-concept and view of the future, would influence one to take proper precautions against a deadly infection. However, the data indicate quite the opposite. Indeed, these data suggest that the greater one's subjective control and life meaning, the less perceived vulnerability one feels of acquiring a fatal disease and therefore, the less likely one is to take preventive action. These conclusions are consistent with the other pathways from subjective control and life meaning to perceived risk (-.22), and from perceived risk to AIDS preventive behavior (-.33), which were both in a negative direction. Perhaps experiencing oneself as in control and heading towards a meaningful future can act as an inhibitor to worries or fears of vulnerability to AIDS. A person who has a clear vision of the future and the feeling of being capable of creating that future is more likely to feel protected from rịk. Clearly, there is an element of denial in this dynamic, which is potentially dangerous for the college population, where vulnerability to the AIDS virus is more of a reality than these students may want to believe. This should be explored more fully in future studies.

The negative relationship between the constructs of perceived risk and AIDS preventive behavior is inconsistent with research on other health-related dimensions specifical- 
ly using the Health Belief Model (Janz \& Becker, 1984). This Model emphasizes the relevance of a dimension called perceived susceptibility in predicting health-related behavior change, and purports that the greater the perceived susceptibility, the more likely the person is to change his/her health-related behavior. However, researchers who have studied the relationșhip of AIDS perceived risk to preventive behavior with adolescents have found that either perceived risk is unrelated to AIDS preventive behavior (Weisman, et. al., 1989) or that the more perceived susceptibility, the greater the adolescent's anxiety, and the less likely he/she is to take AIDS preventive action (Kegeles, et. al., August, 1990). It is possible that the inconsistencies in the research relevant to the construct of perceived risk are a function of the age of the sample. Studies using the Health Belief Model have been mostly conducted with older adult samples. The attitudes of adolescents and young adults, and their related feelings of invulnerability and denial of death could create a different effect on their commitment to preventive behavior than that seen with adults. Perhaps taking AIDS preventive action may signify an acceptance of risk to the young adult, which would conflict with the assumption that he/she is invulnerable. Further study needs to address the relationship between these variables to gain a better understanding of how they relate among the adolescent and young adult populations. 
In addition to the significance of the regression coefficients, an assessment of the prediction error and squared multiple correlations of the mediating and dependent constructs is pertinent in ascertaining the appropriateness of the model. In general, a large prediction error suggests that the independent and mediating constructs do not account for enough of the variance of the constructs they predict. This signifies the need for the addition of other variables to the structural model. In this study, it was anticipated that other psychosocial variables, besides those examined here, might be relevant to a model of prediction of AIDS preventive behavior. The high prediction errors, ranging from .81 to .95 which were found for the two mediating constructs, self-efficacy (.85) and perceived risk (.95), and the dependent construct, AIDS preventive behavior (.81), bears this out. Indeed, the results indicate that although the model is a good fit to the data, other constructs should be introduced to create a better, more comprehensive model. The large prediction error estimates in this study also support the use of structural modeling techniques for research involving the prediction of complex behaviors, such as sexual behavior. Unlike other statistical techniques, structural modeling is able to separate out and account for prediction error. This allows the researcher to gain an understanding of how precise the constructs in the model are in predicting the dependent constructs, and whether or not 
other constructs are needed in the model.

A parallel indicator of the effectiveness of the constructs in the model is the squared multiple correlation $\left(R^{2}\right)$ derived for each pathway, which ranges from 0 to 1 . In this study, the $\mathrm{R}^{2}$ for AIDS preventive behavior was .19, which indicates that the constructs of subjective control and life meaning, self-efficacy, and perceived risk accounted for $19 \%$ of the variance in AIDS preventive behavior. Thus, one can conclude that a young adult's feelings of control and competence, purpose in life, self-efficacy and perceived vulnerability do account for a portion of determining use or non-use of AIDS preventive behaviors. Although this finding is important and valid in our understanding of what makes an individual take AIDS preventive action, it also underscores the need for further research focusing on not only these, but other important psychological determinants of an AIDS preventive behavior model, such as self-esteem, depression, self-worth, and stress and coping.

The squared multiple correlations for the mediating variables were $R^{2}=.15$ for self-efficacy and $R^{2}=.05$ for perceived risk. These findings suggest that the independent construct of subjective control and life meaning accounts for $15 \%$ of the variance in self-efficacy and $5 \%$ of the variance in perceived risk. For the construct of selfefficacy, the resulting $R^{2}$ is acceptable and indicates that 
a young adult's sense of control relates to the individual's perception that he/she can engage in behaviors which will successfully prevent HIV infection. In contrast, the variance in the construct of perceived risk is mostly unaccounted for by the construct of subjective control and life meaning in the model. This can be seen by the $\mathrm{R}^{2}$ which is quite low (.05) for this construct, and conversely by the prediction error which is quite large (.95). This seems to indicate that feelings of competence and control and a sense of purpose in life, do not, to a large degree, account for how vulnerable a young adult perceives him/her self to be to the AIDS virus. Clearly, there are other, more potent variables which might explain the variability in the perceived risk construct for this population. Perhaps these variables include proximity to, or membership in, a known high-risk population, such as the homosexual or IV drugusing populations. Another potential measure of perceived risk could be AIDS-relevant measures of behavior such as number of sexual partners, and types of sexual contact. Given the negative relationship between perceived risk and AIDS preventive behavior in this sample, and the amount of variation in perceived risk that was unaccounted for by the model, further analyses were conducted to investigate this construct. The model was analyzed using perceived risk as the outcome variable, with AIDS preventive behavior taking its place as the mediating construct. The model was 
designed in this way to explore whether a nonrecursive relationship exists between perceived risk and AIDS preventive behavior. Other researchers who have found a negative relationship between these constructs have proposed that such a bidirectional relationship exists because engaging in risky behaviors influences perception of risk, as perception of risk influences preventive behavior (Emmons, et. al., $1986)$.

The results of these analyses indicate that overall, the model fit is slightly worse with perceived risk as the outcome than it is with AIDS preventive behavior as the outcome variable. Both models, however, were shown to be plausible representations of the data. With perceived risk as the outcome, the results show a significant, negative relationship between AIDS preventive behavior and perceived risk. This finding suggests that if one engages in risky behaviors, one is less likely to perceive oneself as being at risk for HIV contraction. Unfortunately, these analyses can not fully explain the relationship between these two variables, other than to say that they appear to be negatively associated in this sample. The data in this study is cross-sectional, and to ascertain the direction of the relationship among these variables, one would need to conduct a longitudinal study.

Another interesting finding in regards to how well the model explains the construct of perceived risk involves 
differences found between men and women when comparisons of the model were analyzed. Multiple squared correlations for the dependent construct of AIDS preventive behavior were somewhat similar for men and women, where $R^{2}=.20$ for men and $R^{2}=.17$ for women. For the construct of self-efficacy, multiple squared correlations were less similar with $R^{2}$ $=.17$ for men and $\mathrm{R}^{2}=.13$ for women. These values indicate that the model is slightly more effective at explaining the construct of self-efficacy for men than it is for women. However, even more notable are the estimates of the multiple squared correlations for the construct of perceived risk, where $R^{2}=.10$ for the men and $R^{2}=.03$ for the women. This finding suggests that for women, a sense of competence and ability to control their own lives does not explain their perceptions of risk regarding HIV infection. For men, however, feelings of control and meaning in life do, to some extent, explain their perceptions of how at risk they are for HIV infection. These gender differences, for how well the model explains the variability in the construct of perceived risk, are not easily interpretable. Yet, it is possible to understand these findings in terms of what is involved in specific AIDS preventive behaviors. One of the most well-known ways in which HIV infection is prevented is through condom use. In order for condom use to occur, a woman may have to insist that the man put a condom on, whereas a man merely needs to, himself, make the decision to 
wear one. In effect, the woman in this situation has less control than the man. Her preventive behavior seems to be less dependent on her own internal feelings and more dependent on her effective communication skills, than is the man's preventive behavior, because it is his body which is at issue. Thus, perhaps a woman's perception of her risk, is mediated by variables which tap more into her communication skills in her current sexual relationships and how secure she feels about controlling her own and her partner's sexual behavior.

In a paper presented at a symposium conducted at the American Psychological Association convention, focusing on AIDS risking behavior in adolescents, Kegeles and her colleagues (August, 1990) described results from a study which add credence to these interpretations. These researchers found that white adolescent women who stated that they had the power to get their partners to use condoms reported less perceived susceptibility to HIV infection, and were, indeed, using condoms more often. In contrast, Latina adolescent women who felt less control in their relationships to men, reported more perceived susceptibility and less condom use. Strunin (August, 1990) found similar results in her study of adolescent women, and concluded that if the women wanted their partners to use condoms, their partners were six times more likely to do so. Thus, it seems that perceived control is an important psychological variable influencing both 
perceived risk and AIDS preventive behavior, especially for women. Yet, as it is measured in this study, subjective control and life meaning, is perhaps, too general and broad to capture the kind of perceived control that is involved in predicting perceptions of risk and AIDS preventive behavior in women. Future studies might work to develop a more specific measure of these constructs that is more directly relevant to AIDS preventive behavior.

Apart from the gender differences discussed above, a comparison of the pattern of relationships for men and women found mixed results regarding gender differences. The model was analyzed with men only, with women only, and in a multisample model which tested for differences on individual parameter estimates. The results of the separate analyses conducted on the model for men and women indicate that the overall model is plausible for both genders. This finding adds further support to the validity of the model. Analysis of the multisample model was conducted to establish whether or not the specific relationship among the constructs is different for men and women, as differences were hypothesized among the pattern of relationships on three constructs of subjective control and life meaning, self-efficacy and AIDS preventive behavior. The model was analyzed with four pathways constrained to be equal; the two factor loadings from the variables powerlessness and subjective competence to subjective control and life meaning, and the regression 
coefficients from subjective control and life meaning and self-efficacy to AIDS preventive behavior. A chi-square statistic was generated for each constraint which, if significant, would imply that the pathway needed to be free to vary in order for the model to be a good fit of the data. All four constrained pathways resulted in nonsignificant chi-squares, indicating that the relationships among the constructs were judged to be similar for men and women. These results suggest that the ways in which subjective control and self-efficacy relate to AIDS preventive behavior in the model do not differ according to gender. Thus, subjective control and self-efficacy are not only significantly associated with AIDS preventive behavior, but they are also comparable in the ways in which they are related to preventive behavior in men and women.

An examination of mean differences on the variables for men and women did reveal some significant differences, although the results did not support the original hypotheses. A MANOVA conducted on the data depicted overall gender differences on the dependent measures of the twelve AIDS items for AIDS self-efficacy, AIDS perceived risk, AIDS preventive behavior, and on the two separated measures of subjective control and life meaning. Follow-up, individual ANOVAS revealed significant differences on some items in the AIDS scales, but no significant differences on measures of subjective control or life meaning were found. Thus, it 
appears that in this sample, the hypothesis that women would score lower on measures of subjective control was not supported. Likewise, the hypothesis that women would score lower on measures of AIDS self-efficacy was not borne out. In this sample, women reported slightly higher, though significant, feelings of self-efficacy than men. Results showed that women believed they can take steps to prevent HIV infection, they are fairly selective of their partners, they are careful not to put themselves in risky situations, and they ask their partners questions about sexual history. Although the literature on gender differences purports that men tend to score higher on measures of self-efficacy than women, this study found quite the opposite. Perhaps when it comes to sexual behavior, women feel more efficacious than men because, in general, they have more experience with taking responsibility in the sexual encounter. Other significant mean differences were found on three of the perceived risk items, where men felt slightly more at risk of getting AIDS, and reported greater feelings of vulnerability due to sexual intercourse they had had with risky partners in the last ten years. Women reported feeling more worried about getting AIDS then did the men. These findings depict men as feeling at risk because of tangible past and current sexual behavior, whereas women in this sample seem to feel a more amorphous sense of vulnerability which is less tied to their current risk-taking behavior. This finding is further 
evidenced by significant mean differences found on the AIDS preventive behavior items. In this sample, women showed significantly more AIDS preventive behavior, reporting more abstention from intercourse, fewer sexual partners, and less sexual intercourse after using alcohol and drugs. Out of the twelve AIDS items on the three scales, only reported condom use and fear of previous exposure to the AIDS virus showed no significant gender differences.

Overall, these analyses add to our understanding of why certain individuals engage in AIDS preventive behavior and others do not. Clearly, psychological variables do mediate AIDS preventive behavior in young adults. However, it is also clear from this research that identification of other psychosocial, behavioral, and cultural factors are necessary for a comprehensive model of AIDS preventive behavior. Although education about AIDS prevention is important, previous research has shown that knowledge about how to prevent contraction of the AIDS virus is not a sufficient impetus for behavioral change. In most studies, college students display high levels of knowledge about the AIDS epidemic, yet they still engage in behaviors which put them at risk (Manning, et. al., 1989; Price, et. al., 1988; Strunin, 1987). Some research has focused on the social norms which potentially influence preventive behaviors, such as condom use (Ekstrand, et. al., 1990; Fisher, 1988; Strunin, August, 1990). This research has shown that cultural 
values and peer attitudes and behavior do play an important role in whether an individual is more likely to take preventive action. Surely, a model which predicts AIDS preventive behavior should take these factors into account. But what does the present study tell us about the relevant psychosocial factors involved in AIDS prevention, and what are the implications for intervention?

The construct of subjective control and life meaning is an existential psychological construct which defines an individual's sense of being able to control his/her life situation. It also measures the person's feelings of meaning and purposefulness in life. This construct seems to be most relevant to AIDS preventive behavior, of the variables examined in this study, in how these feelings relate to the individual's sense of self-efficacy, and perceived control in the situation of AIDS risking behavior. The greater the subjective control and life meaning, the greater the persons's sense that he/she has the ability to control a high risk situation and therefore, the more likely preventive behavior will occur. How can this information be useful in developing interventions?

One response would be to target intervention programs which enhance the individual's perception of self-efficacy and self-control. Young adults could learn to identify and anticipate high-risk situations, while at the same time, learn to master alternative, safer behaviors. Becker (1988) 
has proposed intervention programs which respond to the feelings of powerlessness and helplessness that some individuals experience when they are unable to control high-risk situations and end up engaging in risky behavior. He advocates teaching coping mechanisms which could change how people feel about themselves when they do experience a slip or setback. In essence, Becker addresses some of the psychological factors in this study which, he states, motivate and sustain health-related behavior.

Some researchers have proposed intervention programs which target the individual needs of each gender (Wilderman Payne \& Akamatsu, 1990). For example, Weisman and her colleagues (1989) believe that adolescent women need special assistance both in acquiring the communication skills needed to negotiate condom use and feeling comfortable about using their influence in decision-making. They propose the use of group sessions which focus on increasing women's confidence in their ability to effectively avoid high risk behaviors. In essence, this proposal translates into programs which enhance self-efficacy and perceived control.

The results of this study point to the necessity of developing interventions which take into account the many levels at which complex health-related behaviors are influenced. Psychological determinants of behavior, as well as social and cultural determinants, need to be emphasized in any program of health-related behavior change. Researchers 
who study AIDS prevention have consistently exclaimed the need for research which specifically focuses on the psychosocial factors relevant to AIDS preventive behavior (Becker, 1988; Becker \& Joseph, 1988; Cleary, 1988). The present study is an attempt to identify and assess three psychological constructs which could influence AIDS preventive behavior in college students. Indeed, subjective control and life meaning, perceived risk, and self-efficacy were found to be associated with AIDS preventive behavior in this sample.

Yet, it is clear that further research in this area is needed. The model of AIDS preventive behavior analyzed in this study adds to our understanding of what psychological determinants do influence AIDS-relevant behavior change. But the results also show us that other factors need to be included in such a model. For example, future research could examine the variable of perceived control of AIDS preventive behaviors, to determine how this factor relates to AIDS preventive behavior. Also, further studies might examine whether gender differences exist in perceptions of control. Further, the variable of perceived risk should be assessed, both in terms of what influences perceptions of vulnerability in a young adult population and how these perceptions relate to AIDS preventive behavior.

This study could also be replicated with different populations to ascertain how the pattern of relationships of 
these constructs would hold with other data. For example, college students tend to display high levels of subjective competence and purpose in life, and low levels of powerlessness. The construct of subjective control and life meaning was negatively related to perceived risk and AIDS preventive behavior in this sample, which seems to indicate that a sense of power and purposefulness acts as a sort of buffer to feelings of vulnerability and to AIDS preventive action. One interesting question is how this construct of subjective control and life meaning would behave in the model replicated with an increasingly at-risk population, namely heterosexual, minority, urban women. Would this global construct show a positive relationship to AIDS preventive behavior? Would it be associated more with behavior change in this population? Would it need to be made more specific in order to increase relevance to AIDS-risking behavior, in particular? Replicating this study with a more high-risk population, and with some additional psychosocial and behavioral constructs, is a useful direction to take in future work.

The AIDS epidemic has directly challenged behavioral scientists. Although there exists a growing arsenal of research in this field, scientists remain perplexed and frustrated by the complexity involved in changing AIDS highrisk behavior. As the epidemic spreads to the vulnerable populations of adolescents, young adults, and heterosexual women and their unborn infants, it is imperative that AIDS 
research focus on how best to understand and intervene in behavior that puts people at risk. This study represents an attempt to add to the literature on AIDS prevention. At present, it is only through behavioral change and subsequent prevention that we can work toward a solution to this lifethreatening disease. 


\section{References}

Amaro, H. (1988). Considerations for prevention of HIV infection among hispanic women. Psychology of women Quarterly, 12, 429-443.

Ajzen, I., \& Fishbein, M. (1980). Understanding attitudes and predicting social behavior. Englewood Cliffs, NJ: Prentice-Hall.

Bandura, A. (1977). Self-efficacy: Toward a unifying theory of behavioral change. Psychological Review, 84(2), 191215.

Bandura, A. (1982). Self-efficacy mechanism in human agency. American Psychologist, 37(2), 122-147.

Battista, J., \& Almond, R. (1973). The development of meaning in life. Psychiatry, 36, 409-427.

Becker, M.H. (Ed.). (1974). The health belief model and personal health behavior. Health Education Monographs, $\underline{2}$, 324-508.

Becker, M.H. (1988). AIDS and behavior change. Public Health Reviews, 16, 1-11.

Becker, M.H., \& Joseph, J.G. (1988). AIDS and behavioral change to reduce risk: A review. American Journal of Public Health, 78, 394-410.

Bentler, P.M. (1980). Multivariate analysis with latent variables Causal modeling. Annual Review of Psychology, 31, 419-456. 
Bentler, P.M. (1985). EQS structural equations program manual. Los Angeles: BMDP Statistical Software, Inc. Bentler, P.M., \& Bonett, D.G. (1980). Significance tests and goodness of fit in the analysis of covariance structures. Psychological Bulletin, 88, 588-606.

Campbell, N.K., \& Hackett, G. (1986). The effects of mathematics task performance on math self-efficacy and task interest. Journal of Vocational Behavior, 28(2), 149-162. Carmines, E.G. (1986). The analysis of covariance structure models. In W.D. Berry \& M.S. Lewis-Beck (Eds.), New tools for social scientists: Advances and applications in research methods (pp. 23-55). Beverly Hills: Sage Publications.

Carroll, L. (1989). Gender, knowledge about AIDS and change in sexual behavior in a sample of college students. Unpublished Manuscript, University of Rhode Island, Kingston.

Cates, W., \& Bowen, G.S. (1989). Education for AIDS prevention: Not our only weapon. American Journal of Public Health, 79(7), 871-874.

Centers for Disease Control (1986). Additional recommenda tions to reduce sexual and drug-related transmission of human T-lymphotropic virus type III/lymphadenopathyassociated virus. Journal of the American Medical Asso ciation, 255, 1843-1849.

Centers for Disease Control (1989, June 2). Coordinated 
community programs for HIV prevention among intraveneous drug users-California, Massachusetts. Morbidity and Mortality Weekly Report, 38(21), 369-374.

Centers for Disease Control (1991, January 25). HIV infection/AIDS update. Morbidity and Mortality Weekly Report, $40(3), 41-56$.

Centers for Disease Control (1991, March). U.S. cases reported through February 1991. HIV/AIDS Surveillance Report, 1-18.

Chamberlain, K., \& Zika, S. (1988). Measuring meaning in life: An examination of three scales. Personality and Individual Differences, 9(3), 589-596.

Chen, M.S., \& Land, K.C. (1986). Testing the Health Belief Model: LISREL analysis of alternative models of causal relationships between health beliefs and preventive dental behavior.Social Psychology Quarterly, 49(1),45-60. Chilman, C.S. (1983). Adolescent sexuality in a changing American society: Psychological perspectives for the human science professions. New York: Wiley Interscience.

Chou, C.-P., Bentler, P.M., \& Satorra, A. (1989, March). Scaled test statistics and robust standard errors for nonnormal data in covariance structure analysis: $\underline{\text { Monte }}$ Carlo study. Paper presented at American Educational Research Association meetings, San Francisco, CA. Cleary, P.D. (1988). Education and the prevention of AIDS. 
Law, Medicine ㅌ Health Care, 16, 267-273.

Cochran, S.D., \& Mays, V.M. (1988). Issues in the perception

of AIDS risk and risk reduction activities by Black and

Hispanic/Latina women. American Psychologist, 43(11), 949-957.

Coleman, S.B., Kaplan, J.D., \& Downing, R.W. (1986). Life cycle and loss-the spiritual vacuum of heroin addiction. Family Process, 25, 5-23.

Condiotte, M.M., \& Lichtenstein, E. (1981). Self-efficacy and relapse in smoking cessation programs. Journal of Consulting and Clinical Psychoogy, 49, 648-658. Crumbaugh, J.C. (1968). Cross-validation of Purpose-in-Life test based on Frankl's concepts. Journal of Individual Psychology, 24, 74-81.

Crumbaugh, J.C., \& Maholick, L.T. (1964). An experimental study in existentialism: The psychometric approach to Frankl's noogenic neurosis. Journal of clinical Psycholo gy, 20, 200-207.

Cudeck, R., \& Browne, M.W. (1983). Cross-validation of covariance structures. Multivariate Behavioral Research, $18,147-157$

DeFigueiredo, J.M., \& Frank, J.D. (1982). Subjective Imcompetence, the clinical hallmark of demoralization. Comprehensive Psychiatry, 23(4), 353-363.

Ekstrand, M, Shafer, M.A., \& Schalwitz, J. (1990, August). Predictors of sexual behavior of juveniles in detention. 
In S. Kegeles (Chair), Adolescents and AIDS: Risk behav ior and determinants of risk taking. Symposium conducted at the meeting of the American Psychological Association, Boston.

Emmons, C.A., Joseph, J.G., Kessler, R.C., Wortman, C.B., Montgomery, S.B., Ostrow, D.G. (1986). Psychosocial predictors of reported behavior change in homosexual men at risk for AIDS. Health Education Quarterly, 13, 331345 .

Engel, G.I. (1967). The psychological setting of somatic disease: The "giving-up, given-up" complex.Royal Society of Medicine proceedings, 60, 553-555.

Fisher, J.D. (1988). Possible effects of reference groupbased social influence on AIDS-risk behavior and AIDS prevention. American Psychologist, 43(11), 914-920. Flora, J.A., \& Thorensen, C.E. (1988). Reducing the risk of AIDS in adolescents. American Psychologist, 43(11), 965970 .

Frank, J.D. (1974) Persuasion and healing. Baltimore: Johns Hopkins University Press.

Frankl. V.E. (1963). Man's search for meaning. Boston: Beacon Press. Gilliam, G., \& Seltzer, R. (1989). The efficacy of educational movies on AIDS knowledge and attitudes among college students. Journal of American college Health, 37, 261-265. 
Glick, R. (1983). Dealing, demoralization, and addiction: heroin in the Chicago Puerto Rican community. Journal of Psychoactive Drugs, 15(4), 281-292. Godin, G., \& Shepard, R.J. (1985). Gender differences in perceived physical self-efficacy among older individuals. Perceptual and Motor Skills, 60(2), 599-602. Guinan, M.E., \& Hardy, A. (1987). Epidemiology of AIDS in women in the United States. Journal of American Medical Association, 257(15), 2039-2041. Hackett, G. (1985). Role of mathematics self-efficacy in the choice of math-related majors of college women and men: A path analysis. Journal of Counseling Psychology, 32, 4756 .

Harlow, L.L. (1985). Behavior of some elliptical theory estimators with nonnormal data in a covariance structures framework: Monte Carlo Study, Ph.D. Thesis, University of California, Los Angeles.

Harlow, L.L. (1989). Young adult life experience survey. Unpublished questionnaire, University of Rhode Island, Kingston .

Harlow, L.L., \& Grimley, D.M. (in press). Women and AIDS: Incidence, treatment, and prevention strategies. Initiatives.

Harlow, L.L., \& Newcomb, M.D. (1990). Towards a general hierarchical model of meaning and satisfaction in life. Multivariate Behavioral Research, 25(3), 387-405. 
Harlow, L.L., Newcomb, M.D., \& Bentler, P.M. (1986). Depres sion, self-derogation, substance use, and suicide idea tion: lack of purpose in life as a mediational factor. Journal of Clinical Psychology, 42(1), 5-21. Harlow, L.L., Newcomb, M.D., \& Bentler, P.M. (1987). Purpose in Life Test assessment using latent variable methods. British Journal of Clinical Psychology, 26, 235-236. Hayduk, L.A. (1987). Structual equation modeling with LIS REL: Essentials and advances. Baltimore: The Johns Hopkins University Press. Jackson, M.E., \& Tessler, R.C. (1984). Perceived lack of control over life events: antecedents and consequences in a discharged patient sample. Social science Research, $13(3), 287-301$. James, L.R., Mulaik, S.A., \& Brett, J.M. (1982). Causal analysis: Assumptions, models and data. Beverly Hills, CA: Sage Publications. Janz, N.K., \& Becker, M.H. (1984). The health belief model: a decade later. Health Education Quarterly, 11, 1-47. Joreskog, K., \& Sorbom, D. (1986). LISREL: Analysis of linear structural relationships by the method of maximum likelihood. Mooresville, Indiana, Scientific Software, Inc.

Joseph, S.C. (1987). Women with AIDS: New York City. City Health Information, $10(6)$. 
Joseph, J.G., Montgomery, S.B., Emmons, C.A., Kessler, R.C., Ostrow, D.G., Wortman, C.B., O’Brien, K., Eller, M., \& Eshleman, S. (1987). Magnitude and determinants of behav ioral risk reduction: longitudinal analysis of a cohort at risk for AIDS. Psychological Health, 2, 73-96. Judson, F.N. (1989). What do we really know about AIDS control? American Journal of Public Health, 79(7), 878882 .

Kegeles, S.M. (1988). Sexually active adolescents and condoms: changes over one year in knowledge, attitudes, and use. American Journal of Public Health.

Kegeles, S.M., Greenblatt, R., Catina, J., Cardenas, C., Miller, J., Ontiveros, T, \& Coates, T.J. (August, 1990). AIDS risk behavior among hispanic and white adolescent females. In S. Kegeles (Chair), Adolescents and AIDS: Risk behavior and determinants of risk taking. Symposium conducted at the meeting of the American Psychological Association, Boston.

Kennedy, P.H., Starrfield, S.L. \& Baffi, C. (1983). Using LISREL analysis for drug research. Journal of school Health, 53(4), 272-281.

Kolata, G. (1989, October 8 ). AIDS is spreading in teenagers, a new trend alarming experts. The New York Times, pp. 1,30 . 
Koop, C.E. (1987). Surgeon General's report on Acquired Immune Deficiency Syndrome. Public Health Reports, 102, $1-3$.

Lawrence, L., Levy, S.R., \& Rubinson, L. (1990). Self-effi cacy and AIDS prevention for pregnant teens. Journal of School Health, 60(1), 19-24.

Lee, A.M., \& Austin, M. (1986). Sex referent cues, success estimations, and performance of children on a lateral jumping task. Journal of Genetic Psychology, 147(3), 371378 .

Manning, D.T., Barenberg, N., Gallese, L. \& Rice, J.C. (1989). College students' knowledge and health beliefs about AIDS: implications for education and prevention. Journal of American College Health, 37, 254-259. Mantell, J.E., Schinke, S.P., \& Akabas, S.H. (1988). Women and AIDS prevention. Journal of Primary Prevention, 9 , $18-40$.

Marsh, H.W., Balla, J.R., \& McDonald, R.P. (1988). Goodness of fit indexes in confirmatory factor analysis: The effect of sample size. Psychological Bulletin, 103, 391410 .

MCDermott, R.J., Hawkins, M.J., \& Moore, J.R. (1987). AIDS awareness and information sources among selected univer sity students. Journal of American college Health, 5(5), $222-226$. 
McKusick, L., Horstmen, W., \& Coates, T.J. (1985). AIDS and sexual behavior reported by gay men in San Francisco. American Journal of Public Health, 75, 493-496. Melton, G.B. (1988). Adolescents and prevention of AIDS. Professional Psychology Research and Practice, 19(4), 403-408.

Miura, I.T. (1987). The relationship of self-efficacy expectations to computer interest and course enrollment in college. Sex-Roles, 16, 303-311.

Murdaugh, C.L. (Ed.). (1988). Theories and models useful for risk reduction. Cardiovascular Nursing, 24(6), 36-38. Murphy, J.S. (1988). Women with AIDS: sexual ethics in an epidemic. In I.B. Corles \& M. Pittman-Lindeman (Eds.), AIDS: Principles, practices, \& politics, (pp. 65-80). Washington, DC: Hemisphere Publishing Co.

Newcomb, M.D., Bentler, P.M., \& Fahy, B. (1987). Cocaine use and psychopathology: associations among young adults. International Journal of The Addictions, 22(12), 11671189 .

Newcomb, M.D., \& Harlow, L.L. (1986). Life events and substance use among adolescents: mediating effects of perceived loss of control and meaninglessness in life. Journal of Personality and Social Psychology, 51(3), 564577 . 
Padelford, B.L. (1974). Relationship between drug involve ment and purpose in life. Journal of Clinical Psychology, 30, 303-305.

Pender, N.J. (1987). Health promotion in nursing practice. Norwalk, CT: Appleton \& Lange.

Pilecka, B. (1985). Selected personality predictors of renewed suicide attempts in young people. Polish Psychological Bulletin, 16(2), 99-108.

Price, J.H., Desmond, S.M., Hallinan, C., \& Griffin, T.B. (1988). College students perceived risk and seriousness of AIDS. Health Education, 16-20.

Reker, G.T., \& Cousins, J.B. (1979). Factor structure, construct validity and reliability of the seeking of Noetic Goals (SONG) and Purpose in Life (PIL) tests. Journal of Clinical Psychology, 35, 85-91. Rickert, V.I., Jay, M.S., Gottlieb, A., \& Bridges, C. (1989). Adolescents and AIDS: female's attitudes and behaviors toward condom purchase and use. Journal of Adolescent Health Care, 10(4), 313-316.

Ripptoe, P.A. \& Rogers, R.W. (1987). Effects of components of protection-motivation theory on adaptive and maladaptive coping with a health threat. Journal of Personality and Social Psychology, 52(3), 596-604.

Satorra, A., \& Bentler, P.M. (1988a). Scaling corrections for statistics in covariance structure analysis. Los Angeles: UCLA Staistics Series \#4. 
Satorra, A., \& Bentler, P. M. (1988b). Scaling corrections for chi-square statistics in covariance structure analysis. Proceedings of the American statistical Associa tion, 308-313.

Schunk, D.H., \& Lilly, M.W. (1984). Sex differences in selfefficacy and attributions: Influence of performance feed back. Journal of Early Adolescence, 4, 203-213. Sharma, S., Durvasula, S., \& Dilion, W.R. (1989). Some results on the behavior of alternate covariance structure estimation procedures in the presence of non-normal data. Journal of Marketing Research, 26, 214-221. Shean, G.D., \& Fechtman, F. (1971). Purpose in life scores of student marijuana users. Journal of Clinical Psychology, 27, 112-113.

Simkins, L. \& Kushner, A. (1986). Attitudes towards AIDS, Herpes II, and toxic shock syndrome: Two years later. Psychological Reports, 59, 883-891. Stall, R., McKusick, L., Wiley, L., Coates, T.J., \& Ostrow, D.G. (1986). Alcohol and drug use during sexual activity and compliance with safe sex guidelines for AIDS: The AIDS behaviorial research project. Health Education Quarterly, 13(4), 359-371.

Stanton, A.L. (1987). Deteminants of adherence to medical regimens by hypertensive patients. Journal of Behavioral Medicine, 10(4), 377-394. 
Stretcher, V.J., DeVellis, B.M., Becker, M.H., \& Rosenstock, I.M. (1986). The role of self-efficacy in achieving health behavior Health Education Quarterly, 13(1), 73-91. Strunin, L. (1990, August). Are there gender differences in AIDS beliefs and behaviors? In S. Kegeles (Chair), Adolescents and AIDS: Risk behavior and determinants of risk taking. Symposium conducted at the meeting of the American Psychological Association, Boston. Strunin, L., \& Hingston, R. (1987). Acquired immunodeficiency syndrome and adolescents: knowledge, beliefs, attitudes, and behaviors. Pediatrics, 79, 825-828. Sy, F.S., Freeze-McElwee, Y., Garrison, C.Z., \& Jackson, K.L. (1989). Knowledge, perceived risk, and beliefs about AIDS among high school and college students in South Carolina. The Journal of the South Carolina Medical Association, 481-487.

Tabachnick, B.G., \& Fidell, L.S. (1983). Using multivariate statistics. New York: Harper \& Row. Tanaka, J.S. (1984). Some results on the estimation of covariance structure models. Ph.D. Thesis, University of California, Los Angeles.

Taylor, S.E., \& Brown, J.D. (1988). Illusion and well-being: A social psychological perspective on mental health. Psychological Bulletin, 103, 193-210. 
Tucker, L.R., \& Lewis, C. (1973). The reliability coefficient for maximum likelihood factor analysis. Psychome trika, 38, 1-10.

Valdiserri, R.O., Lyter, D.W., Kingsley, L.A., Leviton, L.C., Schofield, J.W., Huggins, J., Ho, M., \& Rinaldo, C.R. (1987). The effect of group education on improving attitudes about AIDS risk reduction. New York state Journal of Medicine, 87, 272-278.

Vollmer, F. (1986). Why do men have higher expectancy than women? Sex-Roles, 14, 351-362.

Weisman, C.S., Nathanson, C.A., Ensminger, M., Teitelbaum, M.A., Robinson, J.C., \& Plitcha, S. (1989). AIDS knowl edge, perceived risk and prevention among adolescent clients of a family planning clinic. Family planning Perspectives, 21(5), 213-217.

Weitzel, M.H. (1989). A test of the health promotion model with blue-collar workers. Nursing Research, 38(2), 99104 .

Wilderman Payne, J. \& Akamatsu, T.J. (1990). AIDS: Factors influencing sexual behavior among college students. Paper presented at the annual meeting of the American Psychological Association, Boston, MA.

Yarcheski, A. \& Mahon, N.E. (1989). A causal model of posi tive health practices: The relationship between approach and replication. Nursing Research, 38(2), 88-93. 
Appendix A

\author{
Subjective Control and Life Meaning \\ Powerlessness scale \\ (see Newcomb \& Harlow, 1986)
}

Fill in the number that indicates your amount of agreement or disagreement with the following statements.

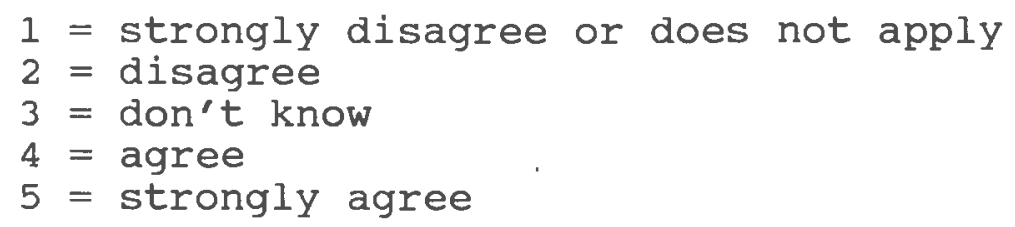

1. I feel I am not in control of my life.

2. I feel that whether or not I am successful is just a matter of luck and chance rather than my own doing.

3. I feel that others are running my life for me.

4. I feel that things just happen to me.

5. I feel stuck where I am.

Note: The final score is the mean of these 5 items, with final scores ranging from 1 to 5 such that higher scores indicate less subjective control.

\title{
Subjective competence scale
}

(Harlow, 1989)

For the following items, indicate how frequently each experience has occurred in the last six months using the following scale.

$$
\begin{aligned}
& 1=\text { Never } \\
& 2=\text { Rarely } \\
& 3=\text { Sometimes } \\
& 4=\text { Often } \\
& 5=\text { Always }
\end{aligned}
$$

1. When faced with a dilemma, I usually know what to do. 2. I feel that I have a sense of inner control over myself. 3. I experience a certain degree of independence in my life. 4. I am able to cope with pressing problems. 
5. I am able to perform tasks in stressful situations.

6. I am able to express feelings appropriately when under stress.

7. When necessary, I am able to turn a situation around for the better.

8. I usually am able to meet the expectations of others.

9. I am able to take action to correct a situation when necessary.

10. I am a self-confident person.

11. I possess a degree of self-determination.

12. I get satisfaction from successfully performing a task.

Note: The final score is the mean of items 1 to 12 , such that scores range from 1 to 5 with higher scores indicating greater subjective competence.

Life Regard Index

(Battista \& Almond, 1973)

Below are a set of statements regarding one's attitudes and feelings about their life. Please read each one and indicate how each one applies to you using the following rating scale.

$$
\begin{aligned}
& 1=\text { does not apply } \\
& 2=\text { rarely applies } \\
& 3=\text { sometimes applies } \\
& 4=\text { usually applies } \\
& 5=\text { strongly applies }
\end{aligned}
$$

1. I feel I have found a really significant meaning for leading my life.

2. I have really come to terms with what's important for me in my life.

3. I have a system or framework that allows me to truly understand my being alive.

4. I have a very clear idea of what I would like to do with my life. to.

5. There are things that I devote all my life's energy 
6. I have a philosophy of life that really gives my living significance.

7. I have some aims and goals that would personally give me a great deal of satisfaction if I could accomplish them.

(r) 8. I just don't know what I really want to do with my life.

(r) 9. I really don't have much of a purpose for living, even for myself.

(r) 10. I need to find something that I can really be committed to.

(r) 11. I get completely confused when I try to understand my life.

(r) 12. There honestly isn't anything that I totally want to do.

(r) 13. I really don't believe in anything about my life very deeply.

(r) 14. Other people seem to have a much better idea of what they want to do with their lives than I do.

15. I have a real passion in my life.

16. I really feel good about my life.

17. Living is deeply fulfilling.

18. I feel that I am living fully.

19. I feel like I am really going to attain what I want in life.

20. I get so excited by what I'm doing that I find new stores of energy I didn't know that I had.

21. When I look at my life I feel the satisfaction of really having worked to accomplish something.

(r) 22. I don't seem to be able to accomplish those things that are really important to me.

(r) 23. Other people seem to feel better about their lives than I do.

(r) 24. I have a lot of potential that I normally don't use. 
(r) 25. I spend most of my time doing things that really aren't very important to me.

(r) 26. Something seems to stop me from doing what I really want to do.

(r) 27. Nothing very outstanding ever seems to happen to me.

(r) 28. I don't really value what I am doing.

Note: The final score is the mean of items 1 to 28 after reverse- scoring the items indicated $(r)$, such that higher scores indicate greater life regard and range from 1 to 5 .

\author{
Purpose in Life \\ (Slightly revised version) \\ (Crumbaugh \& Maholick, 1964) \\ (Harlow, Newcomb, \& Bentler, 1987)
}

Fill in the number that indicates your amount of agreement or disagreement with the following statements.

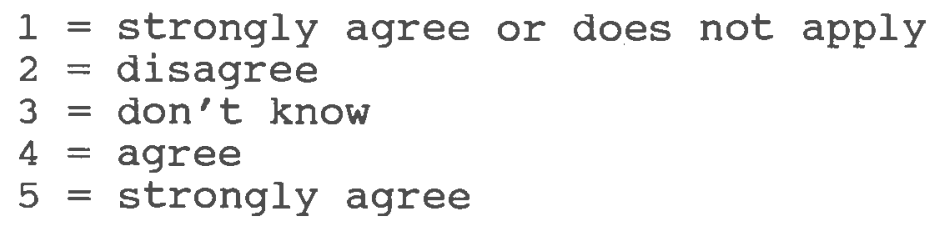

(r) 1. I am usually completely bored.

2. Life to me seems always exciting.

(r) 3. In life I have no goals or aims at all.

(r) 4. My personal existence is utterly meaningless and without purpose.

5. Every day is constantly new and different.

(r) 6. If I could choose, I would prefer never to have been born.

7. After retiring, I would do some kind of the exciting things I have always wanted to do.

(r) 8. In achieving life goals I have made no progress whatsoever.

(r) 9. My life is empty, filled only with despair. 
10. If I should die today, I would feel that my life has been very worthwhile.

(r) 11. In thinking of my life, I often wonder why I exist.

(r) 12. As I view the world in relation to my life, the world completely confuses me.

(r) 13. I am a very irresponsible person.

14. Concerning man's freedom to make his own decisions, I believe man is absolutely free to make all life choices.

15. With regard to death, I am prepared and unafraid. (r) 16. With regard to suicide, I have though of it seriously as a way out.

17. I regard my ability to find a meaning, purpose, or mission in life as very great.

18. My life is in my hands and I am in control of it.

19. Facing my daily tasks is a source of pleasure and satisfaction.

(r) 20. I have discovered no mission or purpose in life.

Note: The final score is the mean of items 1 to 20 after reverse-scoring the items indicated $(r)$, such that higher scores indicate greater purpose in life and range from 1 to 5 . 
Appendix B

Self-Efficacy

AIDS efficacy scale

(Harlow, 1989)

This scale is made up of a list of statements each of which may or may not be true about you. For each statement, choose the most appropriate response from the following.

$$
\begin{aligned}
& 4=\text { Definitely true } \\
& 3=\text { Probably true } \\
& 2=\text { Probably false } \\
& 1=\text { Definitely false }
\end{aligned}
$$

1. I believe that I can take steps to help prevent myself from getting AIDS.

2. I am fairly selective of my sexual partner(s).

3. I am cautious and careful about not getting myself into situations that could lead to getting the AIDS virus.

4. I (would) make it a point to ask questions about my partner's sexual history.

Note: The final score is the average of items 1 to 4 , such that scores range from 1 to 4 with higher scores indicating greater self-efficacy. 
Appendix $C$

Perceived Risk

AIDS perceived risk

(Harlow, 1989)

This scale is made up of a list of statements each of which may or may not be true about you. For each statement, choose the most appropriate response from the following.

$$
\begin{aligned}
& 4=\text { Definitely true } \\
& 3=\text { Probably true } \\
& 2=\text { Probably false } \\
& 1=\text { Definitely false }
\end{aligned}
$$
AIDS.

1. I feel that I am currently at some risk of getting

(r) 2. The thought of getting AIDS does not worry me.

3. I sometimes suspect that I may have been exposed to AIDS.

4. I have had intercourse with someone in the last ten years who could possibly have put me at risk for AIDS.

Note: The final score is the mean of items 1 to 4 after reverse-scoring item $2(r)$, such that higher scores indicate greater perceived control and range from 1 to 4 . 
Appendix D

\section{AIDS Preventive Behavior \\ Aids prevention behavior (Harlow, 1989)}

This scale is made up of a list of statements each of which may or may not be true about you. For each statement, choose the most appropriate response from the following.

$$
\begin{aligned}
& 4=\text { Definitely true } \\
& 3=\text { Probably true } \\
& 2=\text { Probably false } \\
& 1=\text { Definitely false }
\end{aligned}
$$

1. I am currently abstaining from sexual intercourse.

2. When engaging in sexual intercourse, I (would) use condoms.

(r) 3. I often have sex with someone after using alcohol or drugs.

(r) 4. I have had sexual intercourse with several partners in the last ten years.

Note: The final score is the mean of items 1 to 4 after reverse-scoring items 3 and 4 ( $r$ ), such that higher scores indicate greater AIDS preventive behavior and range from 1 to 4 . 
Table 1

Descriptive statistics

\begin{tabular}{|c|c|c|c|c|}
\hline Variable & lean & $\begin{array}{l}\text { Standard } \\
\text { Deviation }\end{array}$ & Skewness & Kurtosis \\
\hline Control & 3.69 & 0.58 & -0.47 & 0.14 \\
\hline Powerlessness & 2.19 & 0.75 & 0.43 & -0.32 \\
\hline Competence & 3.57 & 0.56 & -0.46 & 0.86 \\
\hline Meaning in Life & 3.72 & 0.53 & -0.41 & -0.15 \\
\hline $\begin{array}{l}\text { PII } \\
\text { LRI }\end{array}$ & $\begin{array}{l}3.83 \\
3.61\end{array}$ & $\begin{array}{l}0.52 \\
0.64\end{array}$ & $\begin{array}{l}-0.56 \\
-0.36\end{array}$ & $\begin{array}{l}0.07 \\
0.01\end{array}$ \\
\hline $\begin{array}{l}\text { AIDS Efficacy } \\
\text { AIDS Efficacy }(l g)\end{array}$ & $\begin{array}{l}3.49 \\
0.53\end{array}$ & $\begin{array}{l}0.54 \\
0.08\end{array}$ & $\begin{array}{l}-1.24 \\
-2.03\end{array}$ & $\begin{array}{l}1.32 \\
6.44\end{array}$ \\
\hline $\begin{array}{l}\text { Good Prev. } \\
\text { Selective } \\
\text { Careful } \\
\text { Qx Sex Hx }\end{array}$ & $\begin{array}{l}3.73 \\
3.62 \\
3.57 \\
3.04\end{array}$ & $\begin{array}{l}0.64 \\
0.72 \\
0.76 \\
0.93\end{array}$ & $\begin{array}{l}-2.71 \\
-2.04 \\
-1.87 \\
-0.65\end{array}$ & $\begin{array}{r}7.36 \\
3.67 \\
2.93 \\
-0.52\end{array}$ \\
\hline $\begin{array}{l}\text { AIDS Risk } \\
\text { AIDS Risk (lg) }\end{array}$ & $\begin{array}{l}1.99 \\
0.28\end{array}$ & $\begin{array}{l}0.65 \\
0.14\end{array}$ & $\begin{array}{r}0.63 \\
-0.07\end{array}$ & $\begin{array}{l}-0.13 \\
-0.51\end{array}$ \\
\hline $\begin{array}{l}\text { At Risk } \\
\text { Worried } \\
\text { Exposed } \\
\text { Sex Risk }\end{array}$ & $\begin{array}{l}1.51 \\
3.09 \\
1.65 \\
1.72\end{array}$ & $\begin{array}{l}0.78 \\
1.04 \\
0.91 \\
0.99\end{array}$ & $\begin{array}{r}1.34 \\
-0.76 \\
1.15 \\
1.08\end{array}$ & $\begin{array}{r}0.76 \\
-0.76 \\
0.17 \\
-0.19\end{array}$ \\
\hline $\begin{array}{l}\text { AIDS Prev Behav } \\
\text { AIDS Prev Behav }(l g)\end{array}$ & $\begin{array}{l}2.86 \\
0.43\end{array}$ & $\begin{array}{l}0.81 \\
0.14\end{array}$ & $\begin{array}{l}-0.19 \\
-0.81\end{array}$ & $\begin{array}{r}-0.95 \\
0.22\end{array}$ \\
\hline $\begin{array}{l}\text { Abstain } \\
\text { Condom Use } \\
\text { Fewer Partners } \\
\text { Less Sex, w/Alc, Drg }\end{array}$ & $\begin{array}{l}2.18 \\
3.27 \\
3.01 \\
2.97\end{array}$ & $\begin{array}{l}1.30 \\
0.99 \\
1.27 \\
1.11\end{array}$ & $\begin{array}{r}0.42 \\
-1.08 \\
-0.70 \\
-0.55\end{array}$ & $\begin{array}{l}-1.59 \\
-0.12 \\
-1.28 \\
-1.16\end{array}$ \\
\hline
\end{tabular}

lg = logarithm transformation

**Range on all AIDS items is 1-4.

$\star * *$ Range on Control and Meaning is 1-5. 
Table 2

Descriptive statistics for Men and Women

\begin{tabular}{|c|c|c|c|c|c|c|c|c|}
\hline \multirow[t]{2}{*}{ Variable } & \multicolumn{2}{|c|}{ Mean } & \multicolumn{2}{|c|}{ Standard } & \multicolumn{2}{|c|}{ Skewness } & \multicolumn{2}{|c|}{ Kurtosis } \\
\hline & Men & Women & Men & Women & Men & womén & Men & Women \\
\hline Control & 3.73 & 3.66 & 0.60 & 0.57 & -0.47 & -0.51 & 0.14 & 0.18 \\
\hline Powrless & 2.14 & 2.33 & 0.77 & 0.73 & 0.45 & 0.42 & -0.49 & -0.20 \\
\hline Competenc & 3.60 & 3.55 & 0.58 & 0.53 & -0.37 & -0.45 & 1.00 & 0.63 \\
\hline Meaning & 3.71 & 3.72 & 0.53 & 0.52 & -0.57 & -0.33 & 0.15 & -0.28 \\
\hline PIL & 3.83 & 3.83 & 0.52 & 0.51 & -0.53 & -0.61 & -0.10 & 0.27 \\
\hline LRI & 3.60 & 3.61 & 0.64 & 0.63 & -0.62 & -0.24 & 0.48 & -0.21 \\
\hline AIDSPE & 3.27 & 3.60 & 0.58 & 0.47 & -0.92 & -1.50 & 0.67 & 2.19 \\
\hline $\operatorname{AIDSPE}(1 \mathrm{~g})$ & 0.50 & 0.55 & 0.09 & 0.06 & -1.84 & -2.17 & 5.45 & 7.05 \\
\hline Good Prev** & 3.65 & 3.79 & 0.67 & 0.59 & -2.13 & -3.29 & 5.54 & 11.06 \\
\hline Selective** & 3.36 & 3.77 & 0.83 & 0.60 & -1.21 & -2.90 & 0.78 & 8.43 \\
\hline Careful ** & 3.39 & 3.65 & 0.89 & 0.70 & -1.39 & -2.15 & 1.00 & 4.32 \\
\hline QXSXHX * * & 2.67 & 3.21 & 0.93 & 0.87 & -0.34 & -0.83 & -0.74 & -0.21 \\
\hline AIDSPR & 2.03 & 1.95 & 0.64 & 0.62 & 0.42 & 0.71 & -0.56 & 0.15 \\
\hline AIDSPR ( $1 \mathrm{~g})$ & 0.29 & 0.27 & 0.14 & 0.14 & -0.20 & -0.03 & -0.48 & -0.38 \\
\hline AT Risk* & 1.61 & 1.44 & 0.86 & 0.71 & 1.17 & 1.45 & 0.24 & 1.16 \\
\hline Worried* & 2.98 & 3.17 & 1.07 & 1.01 & -0.59 & -0.86 & -1.01 & -0.53 \\
\hline Exposed & 1.67 & 1.60 & 0.91 & 0.87 & 1.12 & 1.25 & 0.13 & 0.48 \\
\hline Sx Risk** & 1.88 & 1.60 & 1.06 & 0.92 & 0.78 & 1.34 & -0.82 & 0.57 \\
\hline AIDSPB & 2.64 & 3.00 & 0.77 & 0.80 & -0.01 & -0.34 & -0.79 & -0.92 \\
\hline AIDSPB ( lg) & 0.40 & 3.00 & 0.14 & 0.13 & -0.71 & -0.91 & 0.17 & 0.35 \\
\hline Abstain* * & 1.86 & 2.35 & 1.15 & 1.34 & 0.90 & 0.19 & -0.81 & -1.76 \\
\hline Condom Use & 3.28 & 3.28 & 0.91 & 1.01 & -1.09 & -1.08 & 0.20 & -0.19 \\
\hline Few Partn** & 2.61 & 3.27 & 1.33 & 1.55 & -0.13 & -1.19 & -1.77 & -0.31 \\
\hline Ls $S x, A I \& D g *$ & $\star 2.81$ & 3.08 & 1.12 & 1.08 & -0.33 & -0.71 & -1.32 & -0.96 \\
\hline
\end{tabular}

lg = logarithm transformation

The Range on all AIDS items is $1-4$

The Range on Control and Meaning items are 1-5

** Significant Differences were found between men and women on these items where $p<.01$ or better

* Significant Differences found where $p<.05$ or better 
Table 3

Correlation Matrix of 7 Variables in Model

$\begin{array}{lrrrrrr} & \text { AIDSPE } & \text { AIDSPR } & \text { AIDSPB } & \text { PIL } & \text { LRI } & \text { Powrless Competnc } \\ \text { AIDSPE } & 1.00 & & & & & \\ \text { AIDSPR } & -0.31 & 1.00 & & & & \\ \text { AIDSPB } & 0.32 & -0.36 & 1.00 & & & \\ \text { PIL } & 0.36 & -0.21 & -0.04 & 1.00 & & \\ \text { LRI } & 0.26 & -0.15 & -0.01 & 0.67 & 1.00 & \\ \text { Powrless } & -0.26 & 0.15 & 0.04 & -0.72 & -0.60 & 1.00 \\ \text { Competnc } & 0.28 & -0.12 & -0.09 & 0.65 & 0.58 & -0.59\end{array}$

\footnotetext{
AIDSPE = AIDS Self-Efficacy

AIDSPR = AIDS Perceived Risk

AIDSPB $=$ AIDS Preventive Behavior

PIL $=$ Purpose in Life

$L R I=$ Life Regard Index

Powrless $=$ Powerlessness Scale

Competnc $=$ Subjective Competence
} 
Table 4

Indices for Overall Fit of AIDS Preventive Behavior Model

\begin{tabular}{|c|c|c|c|c|}
\hline Index & $\begin{array}{l}\text { Estimation } \\
\text { Procedure }\end{array}$ & Model & $\begin{array}{l}\text { Multisample } \\
\text { Model with } \\
\text { Nine Constraints }\end{array}$ & $\begin{array}{l}\text { Nested } \\
\text { Model }\end{array}$ \\
\hline Chi-square & $\mathrm{ML}$ & 62.42 & 94.83 & 271.62 \\
\hline Chi-square & $S-B$ (robust) & 48.91 & & 226.06 \\
\hline Chi-square & ERLS & 50.18 & 80.71 & 239.1 \\
\hline $\mathrm{DF}$ & & 12 & 33 & 4 \\
\hline RMSR & ML (robust) & 0.03 & 0.05 & \\
\hline RMSR & ERLS & 0.03 & 0.04 & \\
\hline NFI & ML (robust) & 0.96 & 0.94 & \\
\hline NFI & ERLS & 0.97 & 0.95 & \\
\hline NNFI & ML (robust) & 0.94 & 0.95 & \\
\hline NNFI & ERLS & 0.96 & 0.97 & \\
\hline CFI & ML (robust) & 0.97 & 0.96 & \\
\hline CFI & ERLS & 0.98 & 0.97 & \\
\hline PNFI & ML (robust) & 0.55 & 0.74 & \\
\hline PNFI & ERLS & 0.55 & 0.75 & \\
\hline PNNFI & ML (robust) & 0.54 & 0.75 & \\
\hline PNNFI & ERLS & 0.55 & 0.76 & \\
\hline PCFI & ML (robust) & 0.55 & 0.75 & \\
\hline PCFI & ERLS & 0.56 & 0.76 & \\
\hline
\end{tabular}

KEY : $\quad$ ML = Maximum Likelihood Estimation

$\mathrm{S}-\mathrm{B}=$ Satorra-Bentler Scaled Robust statistic

ERLS = Elliptical Estimation

RMSR $=$ Root Mean Squared Residual

NFI $=$ Normed Fit Index

NNFI $=$ Non-normed Fit Index

CFI = Comparitive Fit Index

PNFI = Parsimonious Normed Fit Index

PNNFI = Parsimonious Non-normed Fit Index

PCFI = Parsimonious comparitive Fit Index 
Tabie 5

Standardized Factor Loadings and Error Variances

\begin{tabular}{|c|c|c|c|}
\hline Parameter & $\begin{array}{l}\text { Estimation } \\
\text { Procedure }\end{array}$ & $\begin{array}{l}\text { Factor } \\
\text { Loading }\end{array}$ & $\begin{array}{l}\text { Error } \\
\text { Variance }\end{array}$ \\
\hline \multicolumn{4}{|l|}{ PIL on } \\
\hline Subj.Control \& & ML (robust) & 0.90 & 0.19 \\
\hline Life Meaning & ERLS & 0.90 & 0.19 \\
\hline \multicolumn{4}{|l|}{ LRI on } \\
\hline Subj. Control \& & ML (robust) & 0.75 & 0.43 \\
\hline Life Meaning & ERLS & 0.75 & 0.43 \\
\hline \multicolumn{4}{|l|}{ Powerlessness on } \\
\hline Subj. Control \& & ML (robust) & -0.79 & 0.37 \\
\hline Life Meaning & ERLS & -0.79 & 0.37 \\
\hline \multicolumn{4}{|l|}{ Competence on } \\
\hline Subj. control \& & ML (robust) & 0.74 & 0.45 \\
\hline Life Meaning & ERLS & 0.74 & 0.45 \\
\hline
\end{tabular}

All parameter estimates are significant at $p<.001$ or better 
Table 6

Standardized structural coefficients among constructs

\begin{tabular}{|c|c|c|c|}
\hline Pathway & $\begin{array}{l}\text { Estimation } \\
\text { Procedure }\end{array}$ & $\begin{array}{l}\text { Regression } \\
\text { Coefficient }\end{array}$ & $\begin{array}{l}\text { Prediction } \\
\text { Error }\end{array}$ \\
\hline $\begin{array}{l}\text { Subj. Control } \\
\text { \& Life Meaning } \\
\text { to Self-Efficacy }\end{array}$ & $\begin{array}{l}\text { ML (robust) } \\
\text { ERIS }\end{array}$ & $\begin{array}{l}0.38 \\
0.28\end{array}$ & $\begin{array}{l}0.85 \\
0.85\end{array}$ \\
\hline $\begin{array}{l}\text { Subj. Control } \\
\& \text { Life Meaning } \\
\text { to Perceived Risk }\end{array}$ & $\begin{array}{l}\text { ML (robust) } \\
\text { ERLS }\end{array}$ & $\begin{array}{l}-0.22 \\
-0.22\end{array}$ & $\begin{array}{l}0.95 \\
0.95\end{array}$ \\
\hline $\begin{array}{l}\text { Subj. Control } \\
\text { \& Life Meaning } \\
\text { to AIDS Prev. } \\
\text { Behavior }\end{array}$ & $\begin{array}{l}\text { ML (robust) } \\
\text { ERLS }\end{array}$ & $\begin{array}{l}-0.24 \\
-0.24\end{array}$ & $\begin{array}{l}0.81 \\
0.81\end{array}$ \\
\hline $\begin{array}{l}\text { Self-Efficacy to } \\
\text { AIDS Preventive } \\
\text { Behavior }\end{array}$ & $\begin{array}{l}\text { ML (robust) } \\
\text { ERLS }\end{array}$ & $\begin{array}{l}0.32 \\
0.32\end{array}$ & $\begin{array}{l}0.81 \\
0.81\end{array}$ \\
\hline $\begin{array}{l}\text { Perceived Risk to } \\
\text { AIDS Preventive } \\
\text { Behavior }\end{array}$ & $\begin{array}{l}\text { ML (robust) } \\
\text { ERLS }\end{array}$ & $\begin{array}{l}-0.33 \\
-0.33\end{array}$ & $\begin{array}{l}0.81 \\
0.81\end{array}$ \\
\hline
\end{tabular}

All parameter estimates are significant at $p<.001$ or better 
Table 7

Indices of Overall Fit for Model Comparisons of Men and Women

\begin{tabular}{|c|c|c|c|c|}
\hline Index & $\begin{array}{l}\text { Estimation } \\
\text { Procedure }\end{array}$ & $\begin{array}{l}\text { Model with } \\
\text { Men Only }\end{array}$ & $\begin{array}{l}\text { Model with } \\
\text { Women only }\end{array}$ & $\begin{array}{l}\text { Multismpl } \\
\text { Model }\end{array}$ \\
\hline \multirow{3}{*}{\multicolumn{2}{|c|}{$\begin{array}{l}\text { Chi-square } \mathrm{ML} \\
\text { Chi-square } \mathrm{S}-\mathrm{B} \text { (robust) } \\
\text { Chi-square ERLS }\end{array}$}} & 24.20 & 57.10 & 75.60 \\
\hline & & 22.60 & 50.40 & \\
\hline & & 21.60 & 47.30 & 58.50 \\
\hline DF & & 12 & 12 & 28 \\
\hline RMSR & ML (robust) & 0.03 & 0.03 & 0.03 \\
\hline RMSR & ERLS & 0.03 & 0.03 & 0.03 \\
\hline NFI & ML (robust) & 0.95 & 0.95 & 0.95 \\
\hline NFI & ERLS & 0.96 & 0.96 & 0.96 \\
\hline NNFI & ML (robust) & 0.96 & 0.93 & 0.95 \\
\hline NNFI & ERLS & 0.97 & 0.95 & 0.97 \\
\hline $\mathrm{CFI}$ & ML (robust) & 0.97 & 0.96 & 0.97 \\
\hline CFI & ERLS & 0.98 & 0.97 & 0.98 \\
\hline PNFI & ML (robust) & 0.55 & 0.54 & 0.63 \\
\hline PNF I & ERLS & 0.55 & 0.55 & 0.64 \\
\hline PNNFI & ML (robust) & 0.56 & 0.53 & 0.63 \\
\hline PNNFI & ERLS & 0.56 & 0.54 & 0.65 \\
\hline PCFI & ML (robust) & 0.56 & 0.55 & 0.65 \\
\hline PCFI & ERLS & 0.56 & 0.56 & 0.65 \\
\hline
\end{tabular}

KEY: $\quad$ ML = Maximun Likelihood Estimation

S-B = Satorra-Bentler Scaled Robust Statistic

ERLS = Elliptical Estimation

RMSR = Root Mean Squared Residual

NFI = Normed Fit Index

NNFI $=$ Non-normed Fit Index

CFI = Comparitive Fit Index

PNFI = Parsimonious Normed Fit Index

PNNFI = Parsimonious Non-normed Fit Index

PCFI = Parsimonious Comparitive Fit Index

Note: For the Multisample Model, the ML estimation procedure is not conducted with Robust statistics. 
Table 8

Standardized Factor Loadings and Error Variances for Men and Women

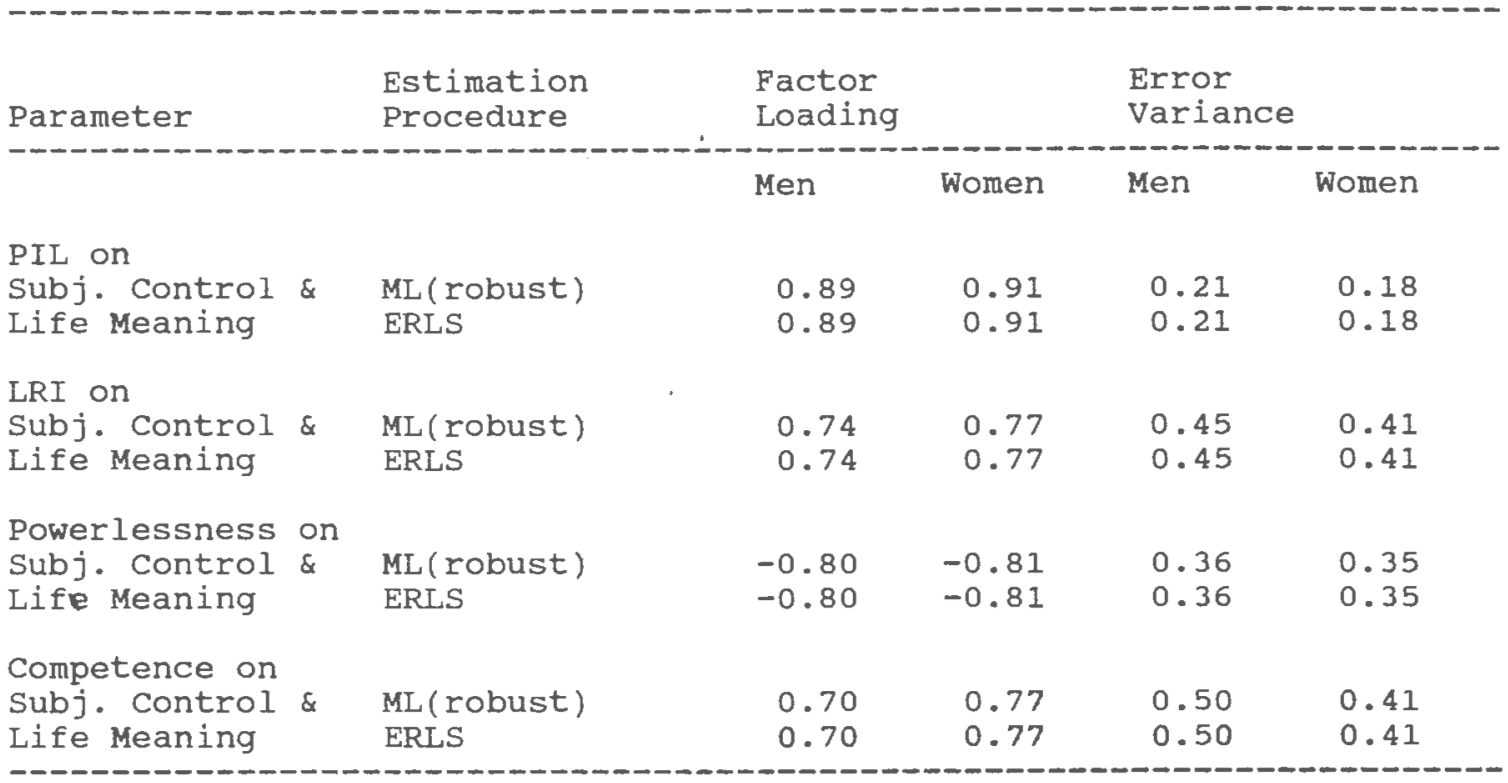

All parameter estimates are significant at $p<.01$ or better 
Standardized Structural Coefficients of the Model for Men and Women

\begin{tabular}{|c|c|c|c|c|c|}
\hline \multirow[t]{2}{*}{ Pathway } & \multirow[t]{2}{*}{$\begin{array}{l}\text { Estimation } \\
\text { Procedure }\end{array}$} & \multicolumn{2}{|c|}{$\begin{array}{l}\text { Regression } \\
\text { Coefficient }\end{array}$} & \multicolumn{2}{|c|}{$\begin{array}{l}\text { Prediction } \\
\text { Error }\end{array}$} \\
\hline & & Men & Women & Men & Women \\
\hline \multicolumn{6}{|l|}{ Subj. Control } \\
\hline \& Life Meaning & $\mathrm{ML}$ (robust) & 0.41 & 0.37 & 0.82 & 0.86 \\
\hline to Self-Efficacy & ERLS & 0.41 & 0.37 & 0.82 & 0.86 \\
\hline \multicolumn{6}{|l|}{ Subj. Control } \\
\hline \& Life Meaning & ML (robust) & -0.32 & -0.17 & 0.90 & 0.97 \\
\hline to Perceived Risk & ERLS & -0.32 & -0.17 & 0.90 & 0.97 \\
\hline \multicolumn{6}{|l|}{ Subj. Control } \\
\hline \& Life Meaning & ML (robust) & -0.23 & -0.21 & 0.80 & 0.83 \\
\hline $\begin{array}{l}\text { to AIDS Prev. } \\
\text { Behavior }\end{array}$ & ERLS & -0.23 & -0.21 & 0.80 & 0.83 \\
\hline \multicolumn{6}{|l|}{ Self-Efficacy to } \\
\hline AIDS Preventive & $\mathrm{ML}$ (robust) & 0.37 & 0.23 & 0.80 & 0.83 \\
\hline Behavior & ERLS & 0.37 & 0.23 & 0.80 & 0.83 \\
\hline \multicolumn{6}{|l|}{ Perceived Risk to } \\
\hline AIDS Preventive & ML (robust) & -0.31 & -0.35 & 0.80 & 0.83 \\
\hline Behavior & ERLS & -0.31 & -0.35 & 0.80 & 0.83 \\
\hline
\end{tabular}

All parameter estimates are significant at $p<.01$ or better 


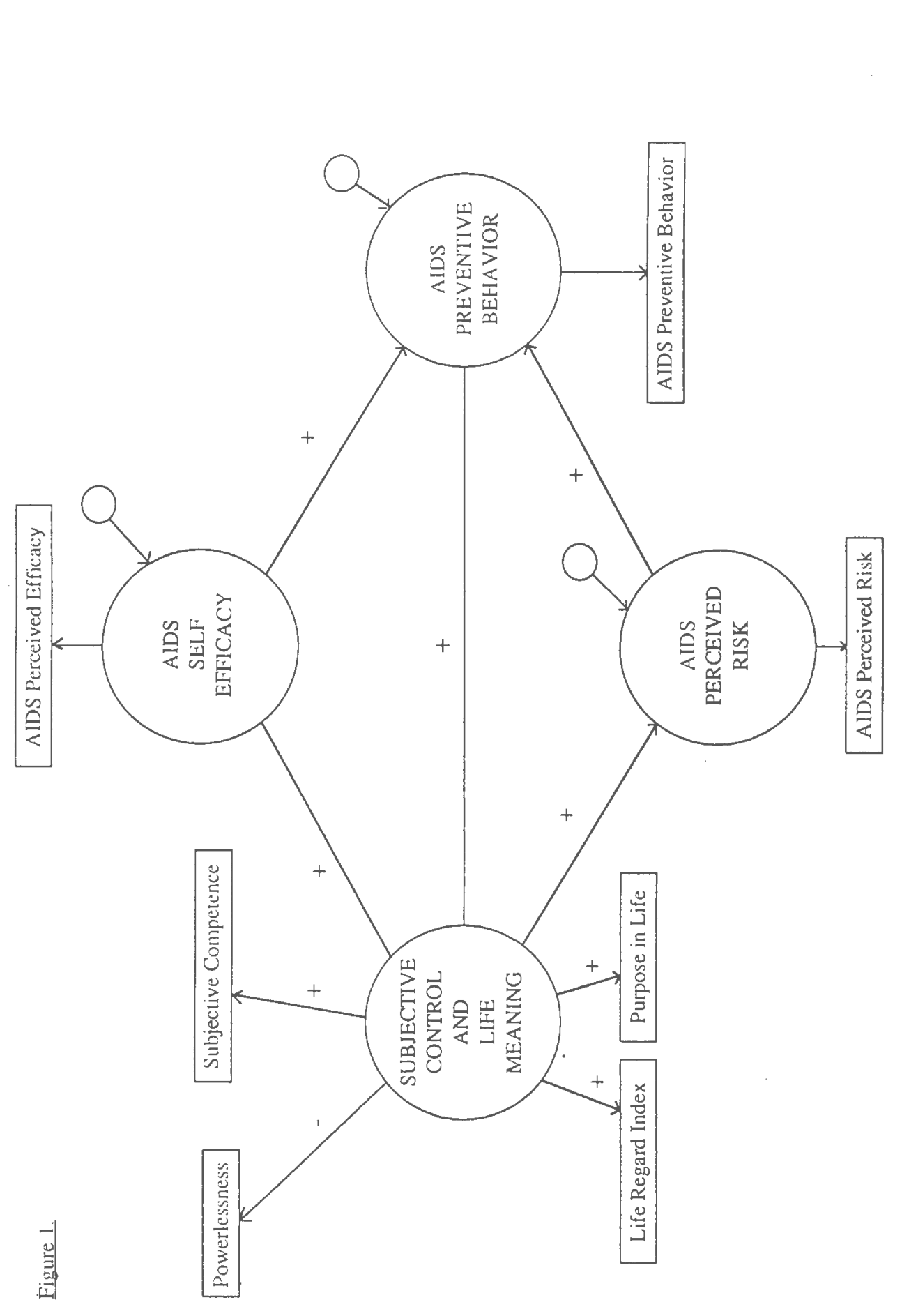

纪.

总芯芯

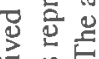

造造宫

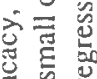

这号

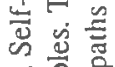

总莡

늘 के

光

踏

옵 氙

원 눈

.

岁通

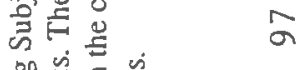

总卷总

政응

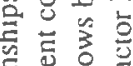

웡

苋范交

导这造

녕

पे

능 $\dot{\widehat{\Omega}}$

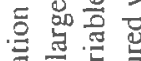

证

बह एँ

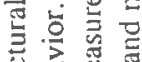

点蛋导

氙胥总

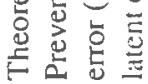




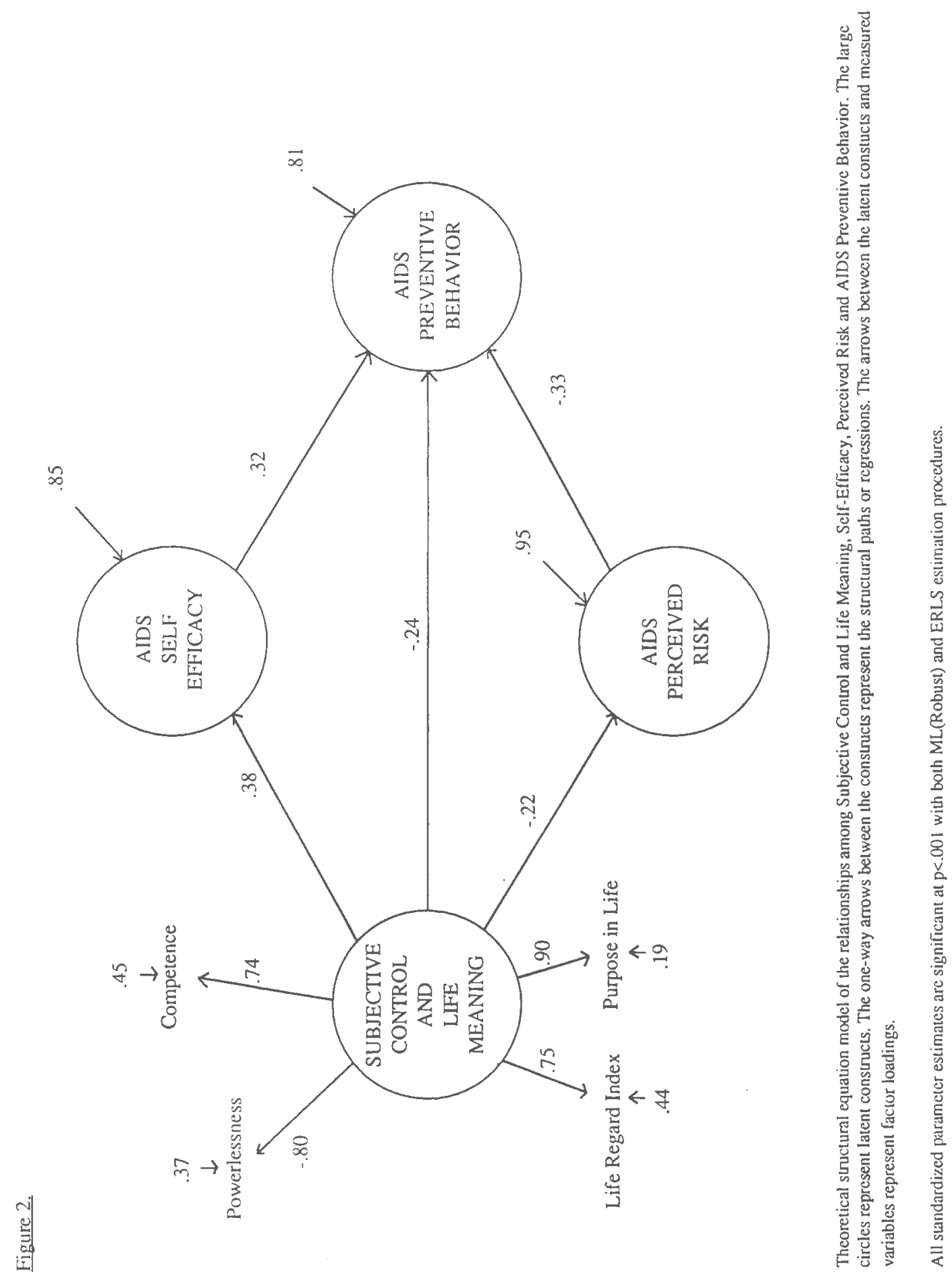




\section{Bibliography}

Amaro, H. (1988). Considerations for prevention of HIV infection among hispanic women. Psychology of women Quarterly, 12, 429-443.

Ajzen, I., \& Fishbein, M. (1980). Understanding attitudes and predicting social behavior. Englewood Cliffs, NJ: Prentice-Hall.

Bandura, A. (1977). Self-efficacy: Toward a unifying theory of behavioral change. Psychological Review, 84(2), 191215 .

Bandura, A. (1982). Self-efficacy mechanism in human agency. American Psychologist, 37(2), 122-147.

Battista, J., \& Almond, R. (1973). The development of meaning in life. Psychiatry, 36, 409-427.

Becker, M.H. (Ed.). (1974). The health belief model and personal health behavior. Health Education Monographs, 2 , $324-508$.

Becker, M.H. (1988). AIDS and behavior change. Public Health Reviews, 16, 1-11.

Becker, M.H., \& Joseph, J.G. (1988). AIDS and behavioral change to reduce risk: A review. American Journal of Public Health, 78, 394-410.

Bentler, P.M. (1980). Multivariate analysis with latent variables Causal modeling. Annual Review of Psychology, 31, 419-456. 
Bentler, P.M. (1985). EQS structural equations program manual. Los Angeles: BMDP Statistical Software, Inc. Bentler, P.M., \& Bonett, D.G. (1980). Significance tests and goodness of fit in the analysis of covariance structures. Psychological Bulletin, 88, 588-606. Campbell, N.K., \& Hackett, G. (1986). The effects of mathematics task performance on math self-efficacy and task interest. Journal of Vocational Behavior, 28(2), 149-162. Carmines, E.G. (1986). The analysis of covariance structure models. In W.D. Berry \& M.S. Lewis-Beck (Eds.), New tools for social scientists: Advances and applications in research methods (pp. 23-55). Beverly Hills: Sage Publications.

Carroll, L. (1989). Gender, knowledge about AIDS and change in sexual behavior in a sample of college students. Unpublished Manuscript, University of Rhode Island, Kingston.

Cates, W., \& Bowen, G.S. (1989). Education for AIDS prevention: Not our only weapon. American Journal of Public Health, 79(7), 871-874.

Centers for Disease Control (1986). Additional recommenda tions to reduce sexual and drug-related transmission of human T-lymphotropic virus type III/lymphadenopathyassociated virus. Journal of the American Medical Asso ciation, 255, 1843-1849.

Centers for Disease Control (1989, June 2). Coordinated 
community programs for HIV prevention among intraveneous drug users-California, Massachusetts. Morbidity and Mortality Weekly Report, 38(21), 369-374. Centers for Disease Control (1991, January 25). HIV infection/AIDS update. Morbidity and Mortality Weekly Report, $40(3), 41-56$.

Centers for Disease Control (1991, March). U.S. cases reported through February 1991. HIV/AIDS Surveillance Report, 1-18.

Chamberlain, K., \& Zika, S. (1988). Measuring meaning in life: An examination of three scales. Personality and Individual Differences, 9(3), 589-596. Chen, M.S., \& Land, K.C. (1986). Testing the Health Belief Model: LISREL analysis of alternative models of causal relationships between health beliefs and preventive dental behavior. Social Psychology Quarterly, 49(1),45-60. Chilman, C.S. (1983). Adolescent sexuality in a changing American society: Psychological perspectives for the human science professions. New York: Wiley Interscience.

Chou, C.-P., Bentler, P.M., \& Satorra, A. (1989, March). Scaled test statistics and robust standard errors for nonnormal data in covariance structure analysis: $\underline{\text { Monte }}$ Carlo study. Paper presented at American Educational Research Association meetings, San Francisco, CA. Cleary, P.D. (1988). Education and the prevention of AIDS. 
Law, Medicine $\underline{\text { Health }}$ Care, 16, 267-273.

Cochran, S.D., \& Mays, V.M. (1988). Issues in the perception

of AIDS risk and risk reduction activities by Black and

Hispanic/Latina women. American Psychologist. 43(11), 949-957.

Coleman, S.B., Kaplan, J.D., \& Downing, R.W. (1986). Life cycle and loss-the spiritual vacuum of heroin addiction. Family Process, 25, 5-23.

Condiotte, M.M., \& Lichtenstein, E. (1981). Self-efficacy

and relapse in smoking cessation programs. Journal of

Consulting and Clinical Psychoogy, 49, 648-658.

Crumbaugh, J.C. (1968). Cross-validation of Purpose-in-Life

test based on Frankl's concepts. Journal of Individual

Psychology, 24, 74-81.

Crumbaugh, J.C., \& Maholick, L.T. (1964). An experimental

study in existentialism: The psychometric approach to

Frankl's noogenic neurosis. Journal of Clinical Psycholo

gy, 20, 200-207.

Cudeck, R., \& Browne, M.W. (1983). Cross-validation of

covariance structures. Multivariate Behavioral Research,

18, 147-157.

DeFigueiredo, J.M., \& Frank, J.D. (1982). Subjective Imcompetence, the clinical hallmark of demoralization. Comprehensive Psychiatry, 23(4), 353-363.

Ekstrand, M, Shafer, M.A., \& Schalwitz, J. (1990, August).

Predictors of sexual behavior of juveniles in detention. 
In S. Kegeles (Chair), Adolescents and AIDS: Risk behav ior and determinants of risk taking. Symposium conducted at the meeting of the American Psychological Association, Boston.

Emmons, C.A., Joseph, J.G., Kessler, R.C., Wortman, C.B., Montgomery, S.B., Ostrow, D.G. (1986). Psychosocial predictors of reported behavior change in homosexual men at risk for AIDS. Health Education Quarterly, 13, 331345 .

Engel, G.I. (1967). The psychological setting of somatic disease: The "giving-up, given-up" complex.Royal Society of Medicine Proceedinas, 60, 553-555.

Fisher, J.D. (1988). Possible effects of reference groupbased social influence on AIDS-risk behavior and AIDS prevention. American Psychologist, 43(11), 914-920. Flora, J.A., \& Thorensen, C.E. (1988). Reducing the risk of AIDS in adolescents. American Psychologist, 43(11), 965970 .

Frank, J.D. (1974) Persuasion and healing. Baltimore: Johns Hopkins University Press.

Frankl. V.E. (1963). Man's search for meaning. Boston: Beacon Press.

Gilliam, G., \& Seltzer, R. (1989). The efficacy of educational movies on AIDS knowledge and attitudes among college students. Journal of American college Health, 37, 261-265. 
Glick, R. (1983). Dealing, demoralization, and addiction: heroin in the Chicago Puerto Rican community. Journal of Psychoactive Drugs, 15(4), 281-292.

Godin, G., \& Shepard, R.J. (1985). Gender differences in perceived physical self-efficacy among older individuals. Perceptual and Motor skills, 60(2), 599-602.

Guinan, M.E., \& Hardy, A. (1987). Epidemiology of AIDS in women in the United States. Journal of American Medical Association, 257(15), 2039-2041.

Hackett, G. (1985). Role of mathematics self-efficacy in the choice of math-related majors of college women and men: A path analysis. Journal of Counseling Psychology, 32, 4756.

Harlow, L.L. (1985). Behavior of some elliptical theory estimators with nonnormal data in a covariance structures framework: A Monte Carlo Study, Ph.D. Thesis, University of California, Los Angeles.

Harlow, L.L. (1989). Young adult life experience survey. Unpublished questionnaire, University of Rhode Island, Kingston .

Harlow, L.L., \& Grimley, D.M. (in press). Women and AIDS: Incidence, treatment, and prevention strategies. Initiatives.

Harlow, L.L., \& Newcomb, M.D. (1990). Towards a general hierarchical model of meaning and satisfaction in life. Multivariate Behavioral Research, 25(3), 387-405. 
Harlow, L.L., Newcomb, M.D., \& Bentler, P.M. (1986). Depres sion, self-derogation, substance use, and suicide idea tion: lack of purpose in life as a mediational factor. Journal of clinical Psychology, 42(1), 5-21. Harlow, L.L., Newcomb, M.D., \& Bentler, P.M. (1987). Purpose in Life Test assessment using latent variable methods. British Journal of Clinical Psychology, 26, 235-236. Hayduk, L.A. (1987). Structual equation modeling with LIS REL: Essentials and advances. Baltimore: The Johns Hopkins University Press.

Jackson, M.E., \& Tessler, R.C. (1984). Perceived lack of control over life events: antecedents and consequences in a discharged patient sample. Social Science Research, $13(3), 287-301$.

James, L.R., Mulaik, S.A., \& Brett, J.M. (1982). Causal analysis: Assumptions, models and data. Beverly Hills, CA: Sage Publications. Janz, N.K., \& Becker, M.H. (1984). The health belief model:

a decade later. Health Education Quarterly, 11, 1-47. Joreskog, K., \& Sorbom, D. (1986). LISREL: Analysis of linear structural relationships by the method of maximum likelihood. Mooresville, Indiana, Scientific Software, Inc.

Joseph, S.C. (1987). Women with AIDS: New York City. City Health Information, $10(6)$. 
Joseph, J.G., Montgomery, S.B., Emmons, C.A., Kessler, R.C., Ostrow, D.G., Wortman, C.B., O'Brien, K., Eller, M., \& Eshleman, S. (1987). Magnitude and determinants of behav ioral risk reduction: longitudinal analysis of a cohort at risk for AIDS. Psychological Health, 2, 73-96. Judson, F.N. (1989). What do we really know about AIDS control? American Journal of Public Health, 79(7), 878882 .

Kegeles, S.M. (1988). Sexually active adolescents and condoms: changes over one year in knowledge, attitudes, and use. American Journal of Public Health.

Kegeles, S.M., Greenblatt, R., Catina, J., Cardenas, C., Miller, J., Ontiveros, T, \& Coates, T.J. (August, 1990). AIDS risk behavior among hispanic and white adolescent females. In S. Kegeles (Chair), Adolescents and AIDS: Risk behavior and determinants of risk taking. Symposium conducted at the meeting of the American Psychological Association, Boston.

Kennedy, P.H., Starrfield, S.L. \& Baffi, C. (1983). Using LISREL analysis for drug research. Journal of School Health, 53(4), 272-281.

Kolata, G. (1989, October 8). AIDS is spreading in teenagers, a new trend alarming experts. The New York Times, pp. 1,30 . 
Koop, C.E. (1987). Surgeon General's report on Acquired Immune Deficiency Syndrome. Public Health Reports, 102, $1-3$

Lawrence, L., Levy, S.R., \& Rubinson, L. (1990). Self-effi cacy and AIDS prevention for pregnant teens. Journal of School Health, 60(1), 19-24.

Lee, A.M., \& Austin, M. (1986). Sex referent cues, success estimations, and performance of children on a lateral jumping task. Journal of Genetic Psychology, 147(3), 371378 .

Manning, D.T., Barenberg, N., Gallese, L. \& Rice, J.C. (1989). College students' knowledge and health beliefs about AIDS: implications for education and prevention. Journal of American College Health, 37, 254-259.

Mantell, J.E., Schinke, S.P., \& Akabas, S.H. (1988). Women and AIDS prevention. Journal of Primary Prevention, 9 , $18-40$.

Marsh, H.W., Balla, J.R., \& McDonald, R.P. (1988). Goodness of fit indexes in confirmatory factor analysis: The effect of sample size. Psychological Bulletin, 103, 391410 .

McDermott, R.J., Hawkins, M.J., \& Moore, J.R. (1987). AIDS awareness and information sources among selected univer sity students. Journal of American College Health, 5(5), $222-226$. 
McKusick, L., Horstmen, W., \& Coates, T.J. (1985). AIDS and sexual behavior reported by gay men in San Francisco. American Journal of Public Health, 75, 493-496. Melton, G.B. (1988). Adolescents and prevention of AIDS. Professional Psychology Research and Practice, 19(4), 403-408.

Miura, I.T. (1987). The relationship of self-efficacy expectations to computer interest and course enrollment in college. Sex-Roles, 16, 303-311.

Murdaugh, C.L. (Ed.). (1988). Theories and models useful for risk reduction. Cardiovascular Nursing, 24(6), 36-38. Murphy, J.S. (1988). Women with AIDS: sexual ethics in an epidemic. In I.B. Corles \& M. Pittman-Lindeman (Eds.), AIDS: Principles, practices, $\underline{\varepsilon}$ politics, (pp. 65-80). Washington, DC: Hemisphere Publishing Co. Newcomb, M.D., Bentler, P.M., \& Fahy, B. (1987). Cocaine use and psychopathology: associations among young adults. International Journal of The Addictions, 22(12), 11671189 .

Newcomb, M.D., \& Harlow, L.L. (1986). Life events and substance use among adolescents: mediating effects of perceived loss of control and meaninglessness in life. Journal of Personality and Social Psychology, 51(3), 564577 . 
Padelford, B.L. (1974). Relationship between drug involve ment and purpose in life. Journal of clinical Psychology, 30, 303-305.

Pender, N.J. (1987). Health promotion in nursing practice. Norwalk, CT: Appleton \& Lange.

Pilecka, B. (1985). Selected personality predictors of renewed suicide attempts in young people. Polish Psychological Bulletin, 16(2), 99-108.

Price, J.H., Desmond, S.M., Hallinan, C., \& Griffin, T.B. (1988). College students perceived risk and seriousness of AIDS. Health Education, 16-20.

Reker, G.T., \& Cousins, J.B. (1979). Factor structure, construct validity and reliability of the seeking of Noetic Goals (SONG) and Purpose in Life (PIL) tests. Journal of Clinical Psychology, 35, 85-91. Rickert, V.I., Jay, M.S., Gottlieb, A., \& Bridges, C. (1989). Adolescents and AIDS: female's attitudes and behaviors toward condom purchase and use. Journal of Adolescent Health Care, 10(4), 313-316.

Ripptoe, P.A. \& Rogers, R.W. (1987). Effects of components of protection-motivation theory on adaptive and maladaptive coping with a health threat. Journal of Personality and Social Psychology, 52(3), 596-604. Satorra, A., \& Bentler, P.M. (1988a). Scaling corrections for statistics in covariance structure analysis. Los Angeles: UCLA Staistics Series \#4. 
Satorra, A., \& Bentler, P. M. (1988b). Scaling corrections for chi-square statistics in covariance structure analysis. Proceedings of the American Statistical Associa tion, 308-313.

Schunk, D.H., \& Lilly, M.W.' (1984). Sex differences in selfefficacy and attributions: Influence of performance feed back. Journal of Early Adolescence, 4, 203-213.

Sharma, S., Durvasula, S.; \& Dillon, W.R. (1989). Some results on the behavior of alternate covariance structure estimation procedures in the presence of non-normal data. Journal of Marketing Research, 26, 214-221.

Shean, G.D., \& Fechtman, F. (1971). Purpose in life scores of student marijuana users. Journal of Clinical Psychology, 27, 112-113.

Simkins, L. \& Kushner, A. (1986). Attitudes towards AIDS, Herpes II, and toxic shock syndrome: Two years later. Psychological Reports, 59, 883-891.

Stall, R., McKusick, L., Wiley, L., Coates, T.J., \& Ostrow, D.G. (1986). Alcohol and drug use during sexual activity and compliance with safe sex guidelines for AIDS: The AIDS behaviorial research project. Health Education Quarterly, 13(4), 359-371.

Stanton, A.L. (1987). Deteminants of adherence to medical regimens by hypertensive patients. Journal of Behavioral Medicine, 10(4), 377-394. 
Stretcher, V.J., DeVellis, B.M., Becker, M.H., \& Rosenstock, I.M. (1986). The role of self-efficacy in achieving health behavior Health Education Quarterly, 13(1), 73-91. Strunin, L. (1990, August). Are there gender differences in

AIDS beliefs and behaviors? In S. Kegeles (Chair),

Adolescents and AIDS: Risk behavior and determinants of risk taking. Symposium conducted at the meeting of the American Psychological Association, Boston. Strunin, L., \& Hingston, R. (1987). Acquired immunodeficiency syndrome and adolescents: knowledge, beliefs, attitudes, and behaviors. Pediatrics, 79, 825-828. SY, F.S., Freeze-McElwee, Y., Garrison, C.Z., \& Jackson, K.L. (1989). Knowledge, perceived risk, and beliefs about AIDS among high school and college students in South Carolina. The Journal of the South Carolina Medical Association, 481-487.

Tabachnick, B.G., \& Fidell, L.S. (1983). Using multivariate statistics. New York: Harper \& Row. Tanaka, J.S. (1984). Some results on the estimation of covariance structure models. Ph.D. Thesis, University of California, Los Angeles.

Taylor, S.E., \& Brown, J.D. (1988). Illusion and well-being: A social psychological perspective on mental health. Psychological Bulletin, 103, 193-210. 
Tucker, L.R., \& Lewis, C. (1973). The reliability coefficient for miximum likelihood factor analysis. Psychome trika, 38, 1-10.

Valdiserri, R.O., Lyter, D.W., Kingsley, L.A., Leviton, L.C., Schofield, J.W., Huggins, J., Ho, M., \& Rinaldo, C.R. (1987). The effect of group education on improving attitudes about AIDS risk reduction. New York state Journal of Medicine, 87, 272-278.

Vollmer, F. (1986). Why do men have higher expectancy than women? Sex-Roles, 14, 351-362.

Weisman, C.S., Nathanson, C.A., Ensminger, M., Teitelbaum, M.A., Robinson, J.C., \& Plitcha, S. (1989). AIDS knowl edge, perceived risk and prevention among adolescent clients of a family planning clinic. Family planning Perspectives, 21(5), 213-217.

Weitzel, M.H. (1989). A test of the health promotion model with blue-collar workers. Nursing Research, 38(2), 99104 .

Wilderman Payne, J.\& Akamatsu, T.J. (1990). AIDS: Factors influencing sexual behavior among college students. Paper presented at the annual meeting of the American Psychological Association, Boston, MA.

Yarcheski, A. \& Mahon, N.E. (1989). A causal model of posi tive health practices: The relationship between approach and replication. Nursing Research, 38(2), 88-93. 